\title{
Observing and Modeling the Response of Placentia Bay to an Extratropical Cyclone
}

\author{
Guangjun $X u^{1,2,3,4,5,6}{ }^{\infty}$, Guoqi Han ${ }^{3, *}$, Changming Dong ${ }^{2,4, *}$, Jingsong Yang ${ }^{5}(\mathbb{C}$ and \\ Brad DeYoung ${ }^{6}$
}

1 Ocean Remote Sensing and Information Technology Laboratory, Guangdong Ocean University, Zhanjiang 524088, China; gjxu@nuist.edu.cn

2 Southern Laboratory of Ocean Science and Engineering (Guangdong Zhuhai), Zhuhai 519000, China

3 Northwest Atlantic Fisheries Centre, Fisheries and Oceans Canada, St. John's, NL A1C 5X1, Canada

4 Oceanic Modeling and Observation Laboratory, Nanjing University of Information Science and Technology, Nanjing 210044, China

5 State Key Laboratory of Satellite Ocean Environment Dynamics, Second Institute of Oceanography, Ministry of Natural Resources, Hangzhou 310012, China; jsyang@sio.org.cn

6 Department of Physics and Physical Oceanography, Memorial University of Newfoundland, St. John's, NL A1B 3X7, Canada; bdeyoung@mun.ca

* Correspondence: Guoqi.Han@dfo-mpo.gc.ca (G.H.); cmdong@nuist.edu.cn (C.D.); Tel.: +1-709-772-4326 (G.H.); +86-25-5869-5733 (C.D.)

Received: 5 October 2019; Accepted: 11 November 2019; Published: 19 November 2019

check for updates

\begin{abstract}
An extratropical cyclone reported to have the largest wind speed in Newfoundland in more than a decade landed on the island of Newfoundland on 11 March 2017. The oceanic responses in Placentia Bay on the southeast coast of Newfoundland to the winter storm were examined using observed data and the Finite-Volume Community Ocean Model (FVCOM). The peak non-tidal water level increase, i.e., storm surge, reached $0.85 \mathrm{~m}$ at St. Lawrence and $0.77 \mathrm{~m}$ at Argentia on Placentia Bay. Sea surface temperature slightly decreased after the storm passage according to buoy and satellite measurements. Root mean square differences (RMSD) of the magnitude of storm surge between model results and observations are $0.15 \mathrm{~m}$. The model sea surface temperature showed a small decrease, consistent with observations, with RMSDs from 0.19 to $0.64{ }^{\circ} \mathrm{C}$ at buoy stations. The simulated surface current changes agree with buoy observations, with model-observation velocity difference ratios (VDR) of 0.75-0.88. It was found that, at Argentia (St. Lawrence), the peak storm surge in Placentia Bay was dominantly (moderately) associated with the inverse barometric effect, and the subsequent negative surge was mainly due to the wind effect at both stations. The sea surface cooling was associated with oceanic heat loss. In the momentum balance, the Coriolis, pressure gradient, and advection terms were all important during the storm, while the first two terms were predominant before and after the storm.
\end{abstract}

Keywords: storm surge; FVCOM; extratropical cyclone

\section{Introduction}

Tropical cyclones (such as hurricanes) and extratropical cyclones can generate strong winds and high coastal storm surges. The combination of storm surge and wind waves can produce significant inundation and cause severe damage in coastal zones [1,2].

Placentia Bay is located on the southeast coast of Newfoundland in the northwestern Atlantic Ocean, bordered by the Avalon Peninsula to the east and the Burin Peninsula to the west (see Figure 1). It supports essential fisheries such as Atlantic cod [3] and emerging aquaculture. It is also an important marine transport route, especially for crude oil tankers. Therefore, it is important to 
improve the understanding of oceanic responses to passing tropical and extratropical cyclones in Placentia Bay, for emergency response, fisheries management, aquaculture regulation and operation, and environment protection.
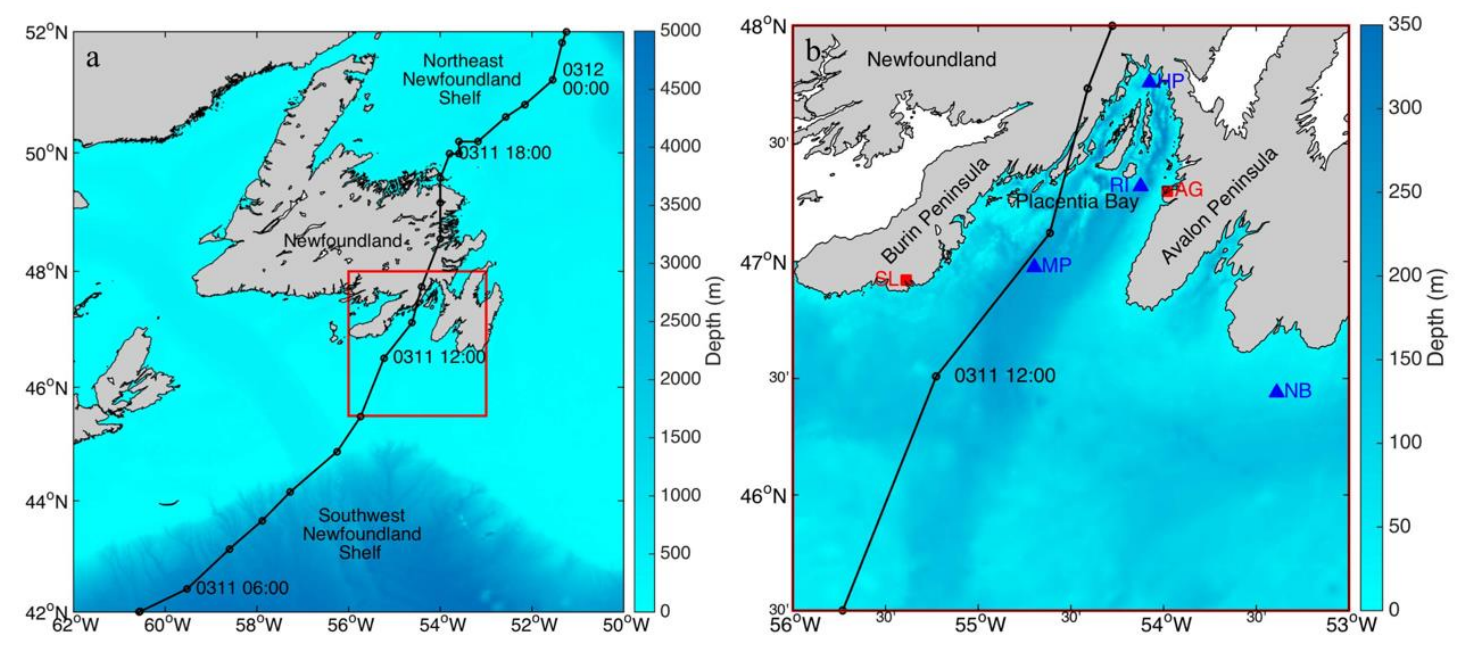

Figure 1. (a) Map showing the study area. The black line is the track of the extratropical cyclone during 11 12 March 2017 and the background color shows the bathymetry of the region. The red box shows the model domain. (b) Map of the model domain. Red squares are tide-gauge stations (SL, St. Lawrence; AG, Argentia) and the blue triangles indicate locations of observation buoys (HP: Head of Placentia Bay; RI: Red Island Shoal; MP: Mouth of Placenta Bay; NB: Nickerson Banks).

Occasionally, Atlantic tropical storms pass over Placentia Bay in summer and fall. Using observational data and modeling results, Han et al. [4] and Ma et al. [5] studied storm surges and other oceanic responses (temperature, currents) to Hurricane Igor on 21 September 2010 off Newfoundland. Han et al. [6] used satellite thermal imagery and ocean color data to examine the impacts of Hurricane Igor on the sea surface temperature (SST) and phytoplankton over the Grand Banks of Newfoundland. Ma et al. [7] investigated the oceanic responses of Placentia Bay to Hurricanes Igor on 21 September 2010 and Leslie on 11 September 2012 using a coastal ocean model and in situ observations. In winter, the Newfoundland area is frequently battered by extratropical cyclones. Extratropical cyclones are a dominant source of mid-latitude weather, and their various formation and evolution mechanisms have been studied using a wide range of observational, theoretical, and modeling approaches [8]. Extratropical cyclones are also the principal cause of storm surge events [9]. Currently, many studies are focused on increasing the prediction precision of extratropical cyclone tracks and assessing the links between the extratropical cyclones and extreme events [10-13]. Using coupled air-sea model solutions, Nelson and He [14] found that air-sea interactions during winter extratropical cyclone outbreaks enhanced ocean heat loss over the Gulf Stream and supported rapid extratropical cyclone intensification. Nevertheless, studies on oceanic responses of Newfoundland waters to extratropical cyclones are limited.

According to online news [15], an exatratropical cyclone passed over Newfoundland on 11 March 2017 (Figure 1), with peak wind speeds up to $44 \mathrm{~m} \mathrm{~s}^{-1}$ at St. John's International Airport. Meteorologists described this storm as the strongest in more than a decade because the peak wind speed broke the record in some regions of Newfoundland. Three-quarters of Newfoundland was affected by the extratropical cyclone, resulting in widespread power outage.

To understand the oceanic responses (such as storm surge, ocean temperature evolution, and current change) in Placentia Bay to the strong extratropical cyclone, we analyze in situ observations and remote sensing data, and apply a coastal ocean circulation model in Placentia Bay and adjacent shelf waters. Furthermore, we aim to discuss the differences between the oceanic responses of Placentia Bay to winter and summer storms, in reference to Ma et al. [7]. 
This manuscript is arranged as follows: In Section 2, we describe the data used and the model setup. Section 3 presents the oceanic responses to the extratropical cyclone using observations and model results. Section 4 discusses the storm surge mechanisms and the momentum balance during the storm. Finally, Section 5 gives the summary and conclusion.

\section{Data and Model Description}

\subsection{Data}

\subsubsection{Remote Sensing Data}

20-Hz Jason-3 along-track altimetry data are produced by CNES (National Center for Space Studies, France) in the framework of the PEACHI project (Prototype for Expertise on AltiKa for Coastal, Hydrology and Ice [16]) and downloaded from the French Archiving, Validation, and Interpretation of Satellite Oceanographic data (AVISO, www.aviso.altimetry.fr). Each track repeats exactly every 9.9156 days. The $20-\mathrm{Hz}$ data have an along-track spatial resolution of about $300 \mathrm{~m}$. An ascending track (Pass 039) of Jason-3 passed over the domain during the extratropical cyclone event. We make corrections for Jason-3 altimetric range data in the $\mathrm{Ku}$ band, including ionospheric delay and sea state bias provided by CNES, radiometer wet tropospheric delay provided by the Jet Propulsion Laboratory (JPL), and dry tropospheric delay provided by the European Center for Medium-range Weather Forecasting (ECMWF). We also correct the altimetry data for geocentric ocean tide using Goddard Ocean Tide 4.8 (GOT4.8 [17]), solid earth tide [18], and pole tide [19]. Finally, we calculate the temporal sea surface height anomalies relative to the sea level averaged from 18 February 2016 to 18 July 2017.

Multiscale Ultrahigh Resolution (MUR) Level 4 SST data [20,21] with spatial resolution of $0.01^{\circ} \times 0.01^{\circ}$ are obtained from the Group for High Resolution Sea Surface Temperature (GHRSST, https://www.ghrsst.org/). The data are produced at the JPL Physical Oceanography Data Distributed Active Archive Center (PO.DAAC), based on in situ data, the Advanced Very High Resolution Radiometer (AVHRR) data, and the Advanced Microwave Scanning Radiometer-EOS (AMSR-E) data.

\subsubsection{In Situ Data}

Tide-gauge data are obtained from the Canadian Hydrographic Service (http://tides.gc.ca/). The data used in this study are hourly time series of water level at the tide-gauge stations St. Lawrence $\left(\mathrm{SL}, 46.92^{\circ} \mathrm{N}, 55.39^{\circ} \mathrm{W}\right.$ ) and Argentia (AG, $47.30^{\circ} \mathrm{N}, 53.98^{\circ} \mathrm{W}$ ) (red squares in Figure 1).

Buoy data, including SST, currents at $0.5 \mathrm{~m}$ below sea surface, and $10 \mathrm{~m}$ wind speed, are downloaded from Environment Canada and SmartAtlantic (http://www.smartatlantic.ca/PlacentiaBay/). The data used are hourly observations at Head of Placentia Bay (HP, $\left.47.76^{\circ} \mathrm{N}, 54.07^{\circ} \mathrm{W}\right)$, Red Island Shoal (RI, $\left.47.32^{\circ} \mathrm{N}, 54.12^{\circ} \mathrm{W}\right)$, Mouth of Placentia Bay (MP, $\left.46.98^{\circ} \mathrm{N}, 54.70^{\circ} \mathrm{W}\right)$, and Nickerson Bank (NB, $46.44^{\circ} \mathrm{N}, 53.39^{\circ} \mathrm{W}$ ) (blue triangles in Figure 1).

Meteorological data are obtained from the Canadian Weather, Climate and Hazard Service (https: //www.canada.ca/en/services/environment/weather.html). Hourly wind speed and wind direction at SL were included in this study.

\subsubsection{Numerical Model Data}

This study makes use of a high-resolution global reanalysis dataset, which include hourly $10 \mathrm{~m}$ wind, heat flux, mean sea level pressure and sea surface height from National Centers for Environmental Prediction (NCEP) Climate Forecast System Version 2 (CFSv2, https://rda.ucar.edu/, [22]). The horizontal resolution for wind, heat flux, and mean sea level pressure is $0.2^{\circ}$, while that for sea surface height is $0.5^{\circ}$.

Hourly temperature and salinity data are obtained from the HYbrid Coordinate Ocean Model (HYCOM [23]). Computations of HYCOM are carried out on a Mercator grid between $78^{\circ} \mathrm{S}$ and $76^{\circ} \mathrm{N}$ 
with horizontal resolution of $1 / 12^{\circ}$ (about $7 \mathrm{~km}$ in our study area) and 32 vertical layers ranging from 0 to $5500 \mathrm{~m}$.

\subsection{Model}

\subsubsection{FVCOM (3.2) Ocean Circulation Model}

With the combined advantages of horizontal grid flexibility and computational efficiency, the FVCOM model [24] is suitable for simulations in area with complex coast lines. FVCOM has been widely used in simulating geophysical dynamic processes in coastal waters $[5,7,25,26]$. For the present application, we run the model with the three-dimensional setup and in the prognostic mode. A barometric pressure term is added in the momentum equations to account for the effect of atmospheric pressure change on sea level. The $\mathrm{k}-\varepsilon$ turbulence model from the General Ocean Turbulence Model (GOTM, http://www.gotm.net/, [27]) is used to calculate the vertical mixing.

\subsubsection{Model Domain and Grid}

The model domain includes Placentia Bay and adjacent shelf waters (see Figure 1b). The geometry of the domain includes several banks and channels.

The triangular grid (Figure 2) is designed using the Surface Water Model System (SMS, www. aquaveo.com/software/sms-learning). The grid resolution is lowest along the open boundary over the continental shelf $(3-5 \mathrm{~km})$ and highest along the coastlines in the inner bay $(50 \mathrm{~m})$. The domain grid consists of 31 unequally spaced sigma levels in the vertical, as well as 25,414 nodes and 47,629 elements in the horizontal. The model bathymetry is derived from General Bathymetric Chart of the Oceans (GEBCO, http://www.gebco.net/), which is in a one arc-minute grid and updated in 2008. To minimize pressure gradient errors [28], the bathymetry is smoothed using the same method as in Ma et al. [29]. The integration time step is set as $0.6 \mathrm{~s}$ for the external mode and $6 \mathrm{~s}$ for the internal mode.

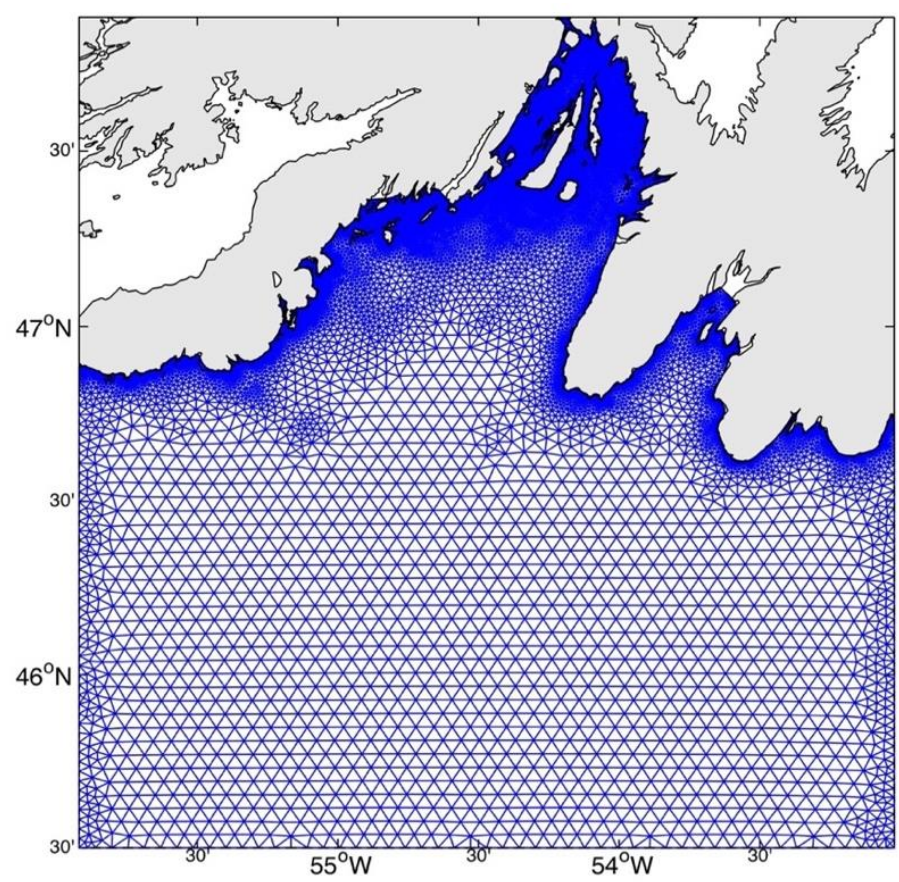

Figure 2. A model mesh with 25,414 nodes and 47,629 elements for Placentia Bay and adjacent shelf waters. 


\subsubsection{Model Forcing, Open Boundary Conditions and Initial Conditions}

The model is forced by spatially and temporally varying winds, air pressure and heat fluxes at the sea surface. Tidal and non-tidal sea levels, temperature and salinity are specified at the open boundary. Hourly, $0.2^{\circ}$ wind speeds at $10 \mathrm{~m}$ above sea surface and barometric pressure field at the sea surface obtained from CFSv2 are interpolated onto the elements and nodes, respectively. Eight dominant tidal constituents (semi-diurnal: M2, S2, N2 and K2; and diurnal: K1, O1, P1 and Q1) are obtained from OTIS (OSU Tidal Inversion Software [30]) and specified along the open boundaries. Non-tidal sea level elevations along the open boundaries are extracted from CFSv2. A difference between non-tidal sea level elevations from CFSv2 and tide-gauge data at stations AG and SL is noted while processing the data. The difference of $0.58 \mathrm{~cm}$ averaged for the two stations and over the model period is added to every open boundary node. River runoff is not considered since it is very low in winter. Initial sea level and velocity of the model are set to zero. The temperature and salinity conditions are initialized from the HYCOM monthly mean output of February 2017.

The model is run from 14 February to 31 March in 2017. The model reaches an approximate dynamic equilibrium after running for 15 days. Hourly results from March 1 to March 31 are analyzed to examine the influence of the extratropical cyclone on sea level, temperature, salinity, and currents in Placentia Bay.

\subsubsection{Model Validation Metrics}

The model results are compared with observational data and evaluated qualitatively and quantitatively by examining their correlation coefficient (cor) and the root mean square differences (RMSD) [7,31]:

$$
R M S D=\frac{1}{N} \sqrt{\sum\left(A_{m}-A_{o}\right)^{2}},
$$

where $A_{m}$ and $A_{o}$ are the model output and observational data, respectively. In addition, the velocity difference ratio (VDR) and the speed difference ratio (SDR) are included to validate the currents. VDR is defined as the ratio of the sum of the squared magnitudes of the vector velocity differences to the sum of the squared magnitudes of the observed velocities, that is:

$$
V D R=\frac{\sum\left|V_{m}-V_{o}\right|^{2}}{\sum\left|V_{o}\right|^{2}}
$$

where $V_{m}$ and $V_{o}$ are the model velocities and the observational velocities, respectively. VDR $=0$ means exact agreement. VDR $<1$ means some agreement; the closer to 0 the better the agreement. VDR $\geq 1$ means little or no agreement. Similarly, SDR is defined as the ratio of the sum of squared speed differences to the sum of the squared magnitudes of the observations, that is:

$$
S D R=\frac{\sum\left(\left|V_{m}\right|-\left|V_{o}\right|\right)^{2}}{\sum\left|V_{o}\right|^{2}} .
$$

VDR is usually larger than SDR, since the former considers not only speed but also direction.

\section{Results}

\subsection{Extratropical Storm Detection}

Extratropical storms are identified from CFSv2, using an automated storm detection and tracking methodology $[32,33]$. Storms are detected according to the minima of air pressure at sea level. We consider a storm for further study based on the following criteria: (i) there is a closed low pressure contour with central air pressure less than $1005 \mathrm{hPa}$, which is generated in the extratropical region from $25^{\circ} \mathrm{N}$ to $55^{\circ} \mathrm{N}$; (ii) the low-pressure system lasts for at least $24 \mathrm{~h}$; and (iii) the storm track is from southwest to northeast. 
As shown in Figure 3, a low-pressure system formed over the northwest Atlantic on 10 March 2017, moving northeastward and gradually intensifying. In the morning of 11 March 2017, the extratropical cyclone arrived on the southwestern Newfoundland Shelf and headed north toward Placentia Bay. It made landfall at about 13:30 (UTC, similarly hereinafter) and crossed over Newfoundland in the afternoon. By the evening of 11 March, the storm center was located on the northeastern Newfoundland Shelf. It stayed in the area for about two days, gradually weakening and eventually dissipating.
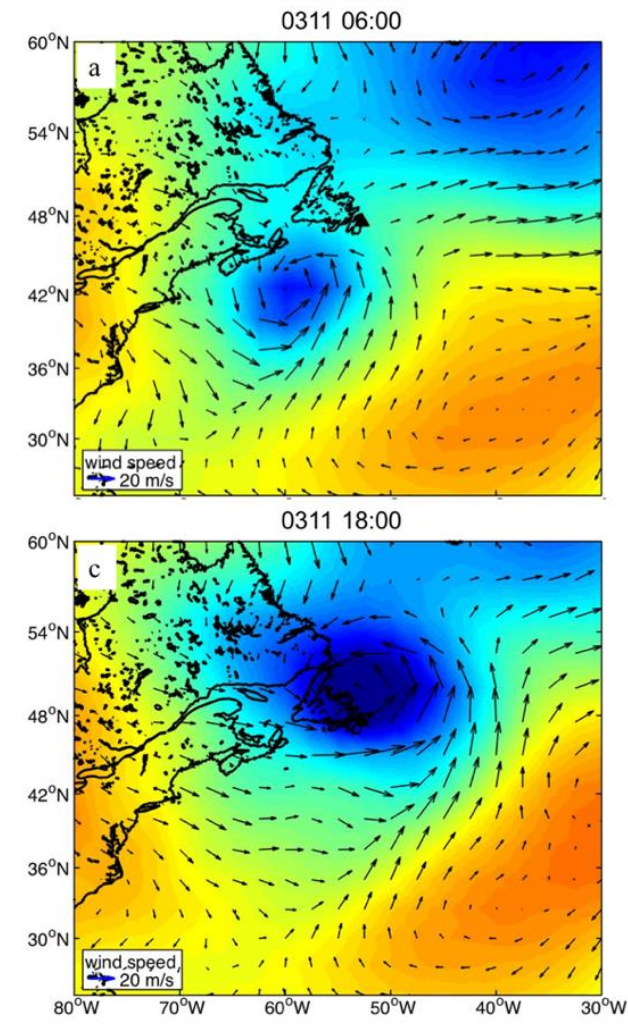

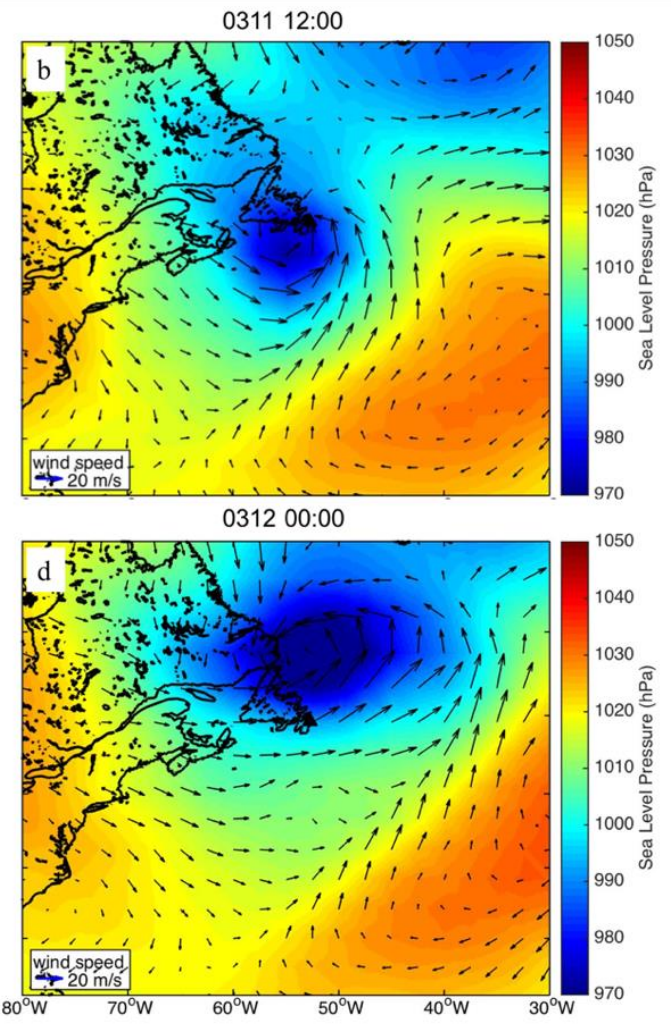

Figure 3. Wind fields (vectors) and sea level pressure (shadows) from CFSv2.

\subsection{Wind}

The predominant wind over the study domain during the winter is eastward [34]. When the extratropical cyclone approached Newfoundland, the dominant wind was southwestward over Placentia Bay (Figure 4). As the storm center moved over Placentia Bay, the observed wind shifted northwestward. The wind direction finally turned northeastward after the storm center left the bay. The maximum hourly wind speed was recorded at $26.6 \mathrm{~m} \mathrm{~s}^{-1}$ over Placentia Bay during the period of 10-16 March 2017. Figure 5 shows the comparison between CFSv2 and observed 10-m winds at four locations in the model domain. 


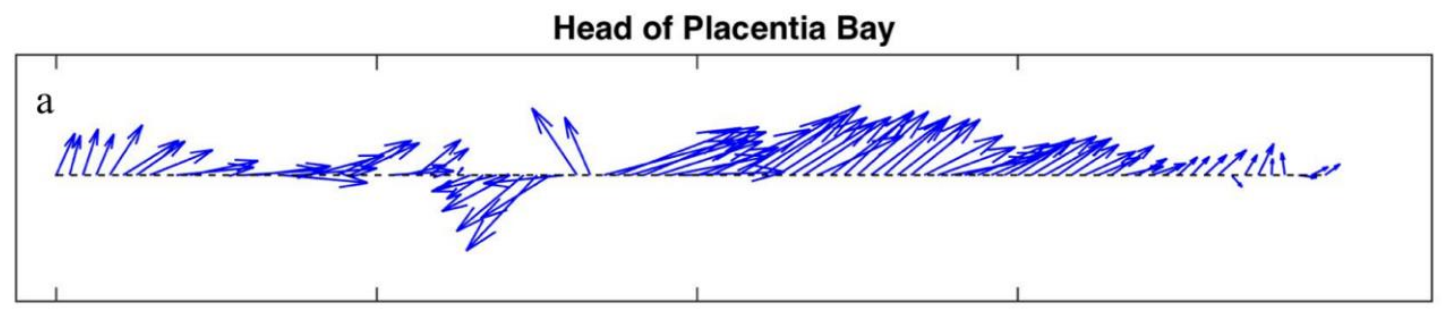

Red Island Shoal

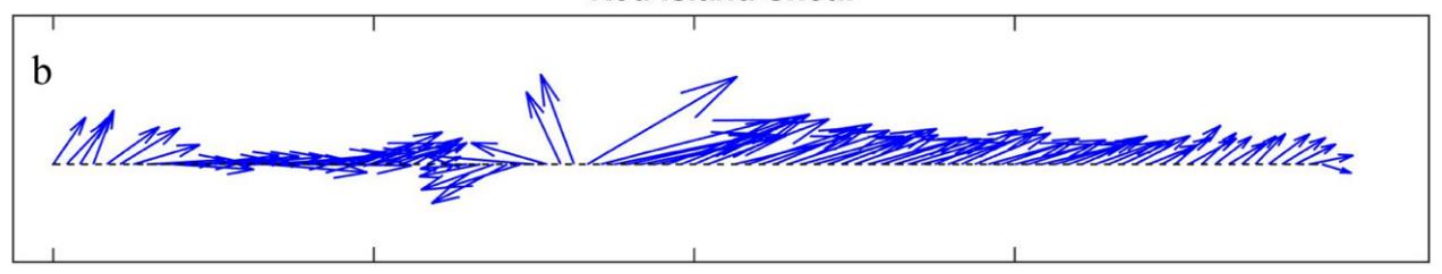

\section{Mouth of Placentia Bay}

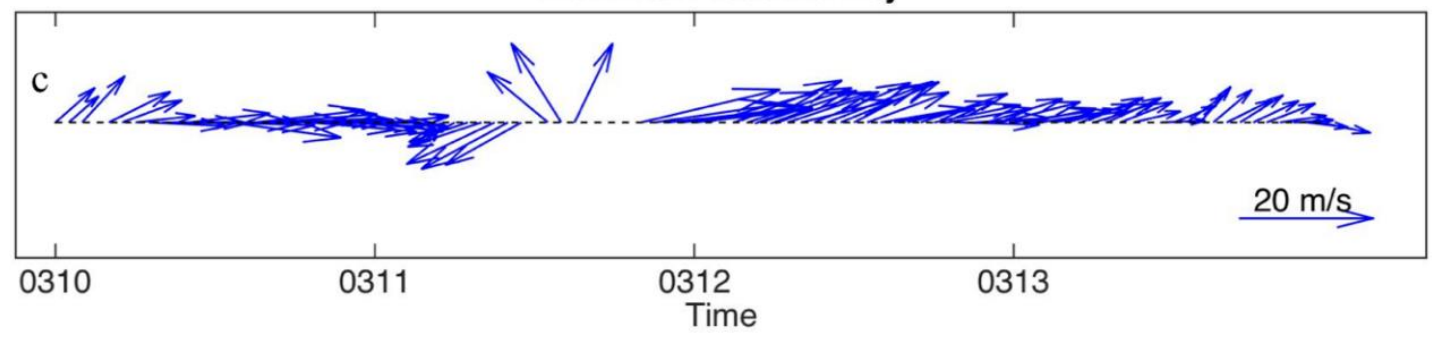

Figure 4. Hourly wind vectors $\left(\mathrm{m} \mathrm{s}^{-1}\right)$ from buoys at HP (a), RI (b), and MP (c) from 10 to 13 March 2017.
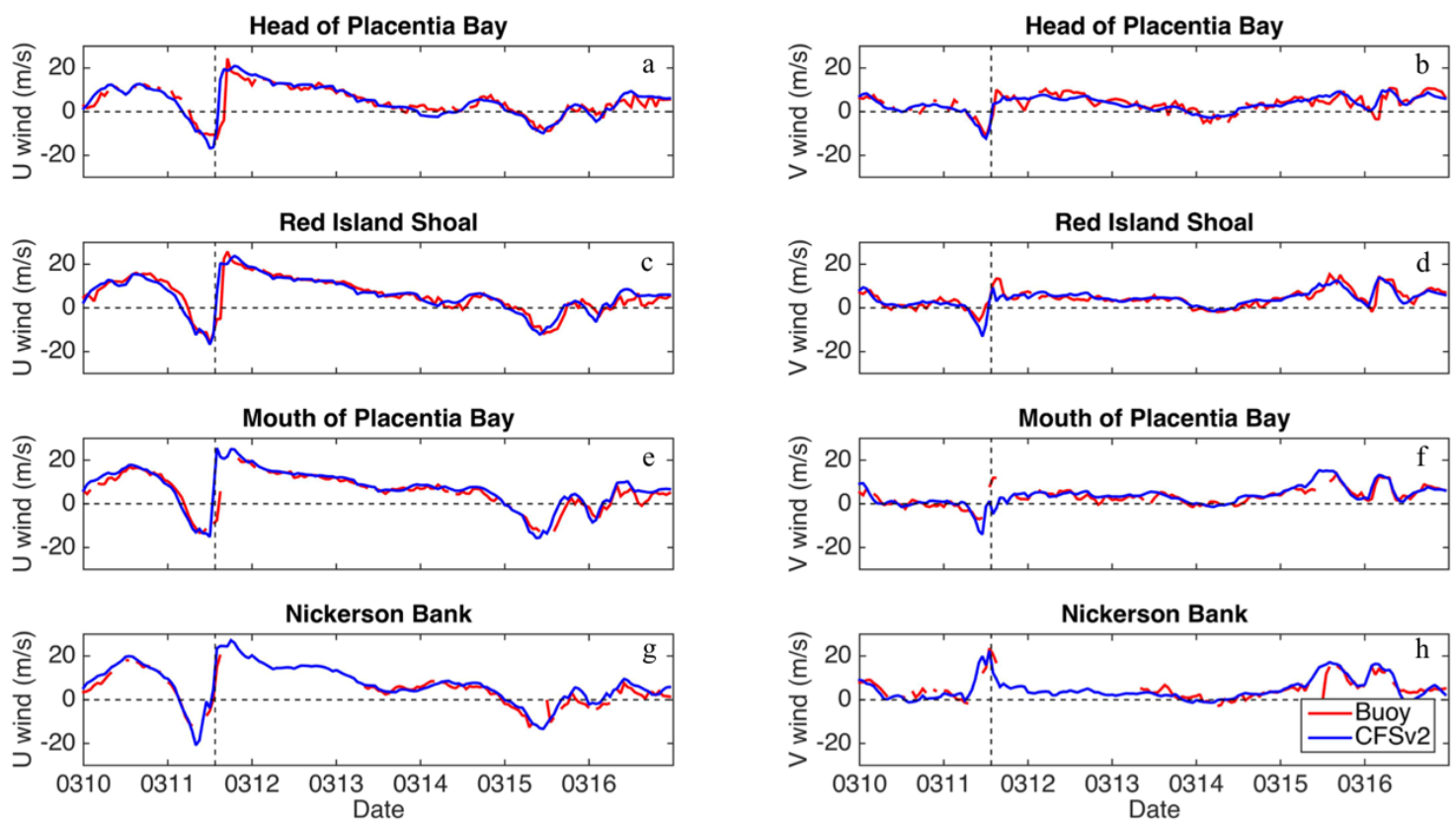

Figure 5. Comparison between buoy (red) and CFSv2 (blue) zonal winds (left panels) and meridional winds (right panels) $\left(\mathrm{m} \mathrm{s}^{-1}\right)$ at $\mathrm{HP}, \mathrm{RI}, \mathrm{MP}$, and NB . The horizontal black dashed lines denote $\mathrm{U}=0 \mathrm{~m}$ $\mathrm{s}^{-1}$ and $\mathrm{V}=0 \mathrm{~m} \mathrm{~s}^{-1}$. The vertical black dashed lines denote the time of landfall. 


\subsection{Storm Surge}

When the storm reaches the bay in the morning of 11 March 2017, the water level increases. Peak surges of $0.85 \mathrm{~m}$ and $0.77 \mathrm{~m}$ are reached at SL (Figure 6a) and AG (Figure 6b), respectively, a few hours after the storm makes landfall. Afterwards a sharp decrease in sea level is seen at SL and AG. Negative surges with magnitudes similar to the preceding positive surges occur in the evening. There is indication of high-frequency oscillations, which may be associated with seiches [7].
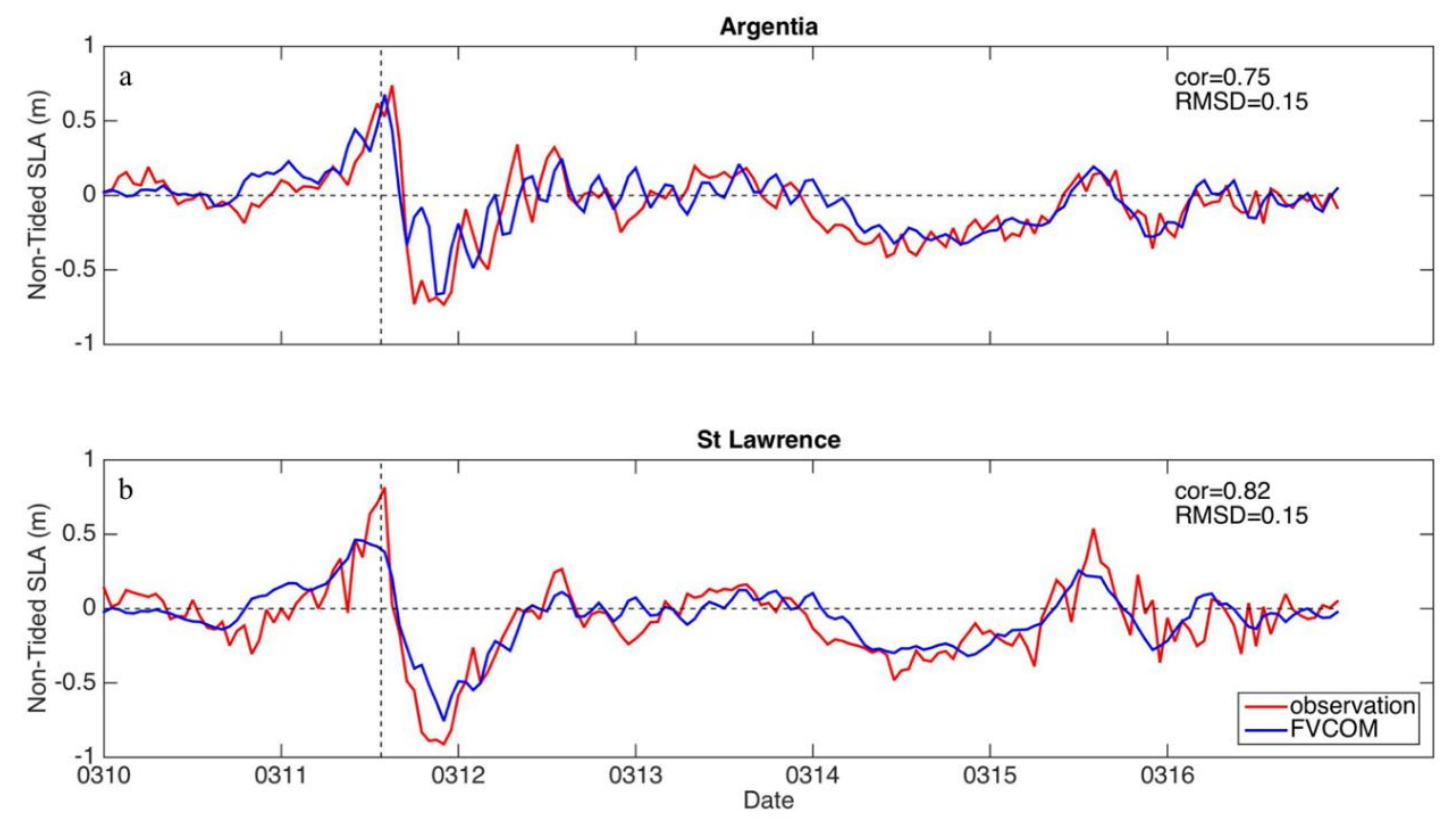

Figure 6. Time series of hourly non-tidal sea level anomalies (m) from tide-gauge observations (red) and model results (blue) at AG (a) and SL (b). The horizontal black dashed lines denote non-tide SLA $=0 \mathrm{~m}$. The vertical black dashed lines denote the time of landfall.

We compare the non-tidal sea level anomalies (defined as non-tidal sea levels minus their mean over the period from 1 to 31 March 2017) from the model solutions with the tide-gauge observations at AG and SL. Tide-gauge data are first detided by using the T-Tide toolbox [35]. Eight tidal constituents (M2, S2, N2, K2, K1, O1, P1, and Q1) are removed from the model results by using the harmonic analysis. The temporal evolutions of hourly non-tidal sea level anomalies from 10 to 16 March 2017 are shown in Figure 6. Correlation coefficients of the model solutions of non-tidal sea level anomalies and observations at AG and SL tide-gauge stations are 0.74 and 0.81, respectively (Figure 6). The peak of sea level anomalies at AG is observed at 15:00 on 11 March, while the model peak occurs at 14:00 (a phase discrepancy of one hour), with a magnitude about $0.1 \mathrm{~m}$ lower than the peak of $0.77 \mathrm{~m}$ from observations. At SL, water levels reach $0.85 \mathrm{~m}$ at 14:00 on 11 March, but the peak of about $0.47 \mathrm{~m}$ from the model solutions occurs four hours earlier. After peaking, sea level starts to decrease rapidly at both stations. The averaged model-observation RMSD for water level is $0.15 \mathrm{~m}$ from 10 March to 16 March, substantially smaller than the peak surge values.

The Jason-3 altimeter passes over Placentia Bay (Figure 7a) during the extratropical cyclone. We calculate along-track sea surface height anomalies based on the altimetry product (Figure $7 \mathrm{~b}$ ). The storm surge is about $0.5 \mathrm{~m}$ near RI (Figure 7b) at 15:07 on 11 March, consistent with the model result but much lower than the tide-gauge value of $0.75 \mathrm{~m}$ at nearby AG. The model underestimation is mainly due to the one-hour phase error as indicated in the comparison with the tide-gauge data (Figure 6a). While the causes for the phase error at this magnitude is complicated and difficult to identify, likely major factors are wind forcing and non-tidal sea levels specified at the open boundary. The Jason- 3 underestimation may be due to errors in altimetric measurements and environmental 
and geophysical corrections [36]. The sea surface height anomalies decrease offshore (Figure 7b). The RMSD of sea surface height anomalies between model and low-pass filtered altimeter observations is $0.12 \mathrm{~m}$.

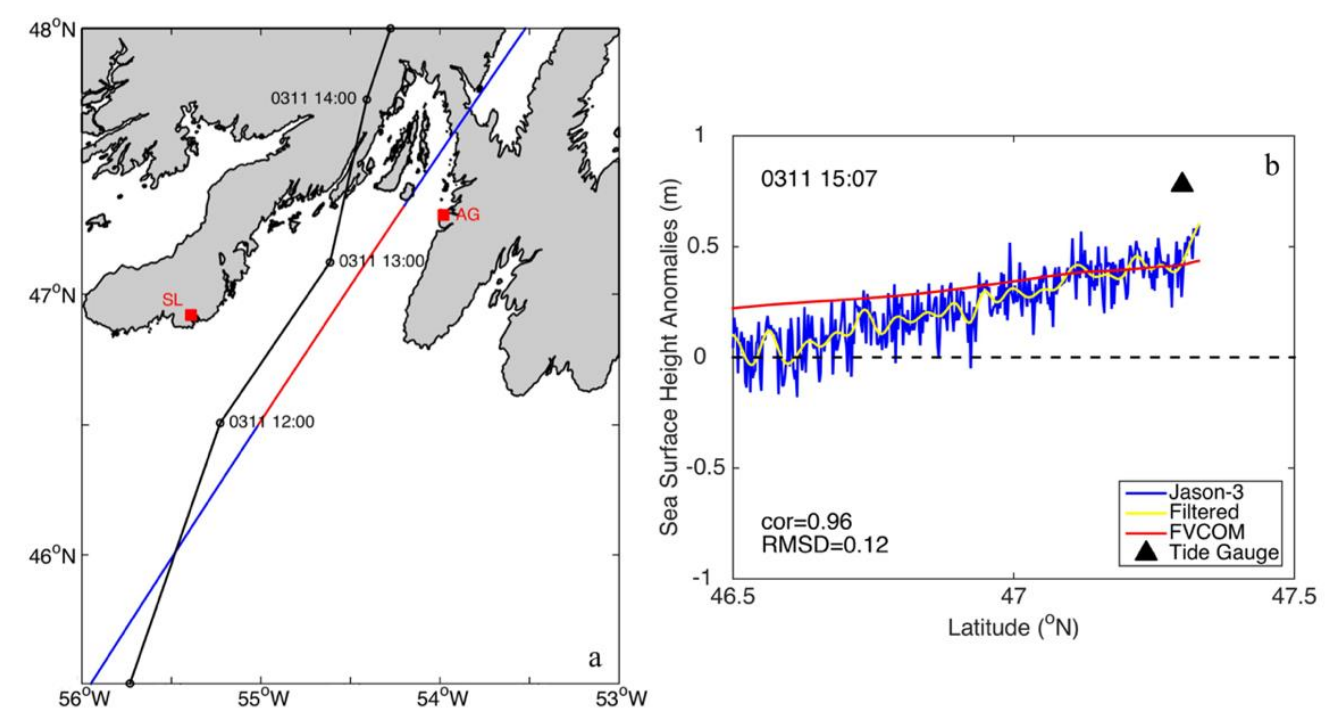

Figure 7. (a) Ground track of Pass 039 from Jason-3 satellite (blue line). The black line denotes the track of the extratropical cyclone. The red squares represent the tide-gauge stations at SL and AG. (b) Jason-3 along-track sea level anomalies with model results along Pass 039 on 11 March 2017. The blue line denotes along-track sea level anomalies, the yellow line denotes low-pass filtered along-track sea level anomalies, the red line denotes FVCOM model results and the black triangle denotes from tide-gauge observations at AG.

\subsection{Temperature}

Comparisons of time series of SST based on buoy measurements and model solutions at HP, RI, MP and NB are shown in Figure 8. SST from buoy observations and model results both decrease slightly, with correlation coefficients from 0.67 to 0.81 at the four buoys. The averaged SST at the four buoy stations from model results drop by $0.45^{\circ} \mathrm{C}$ from 17:00 on 10 March to 11:00 on 13 March, while the averaged SST from buoy observations decrease by $0.33{ }^{\circ} \mathrm{C}$ during the same period. The RMSDs are mostly less than $0.5{ }^{\circ} \mathrm{C}$ at the buoy stations. Therefore, there is an overall good agreement between the observations and the model. Previous studies off the Canadian Atlantic coast reported model-observation SST differences of $1{ }^{\circ} \mathrm{C}$ during Hurricane Juan [37] and 1 to $1.5^{\circ} \mathrm{C}$ during Hurricanes Igor and Leslie [7]. 

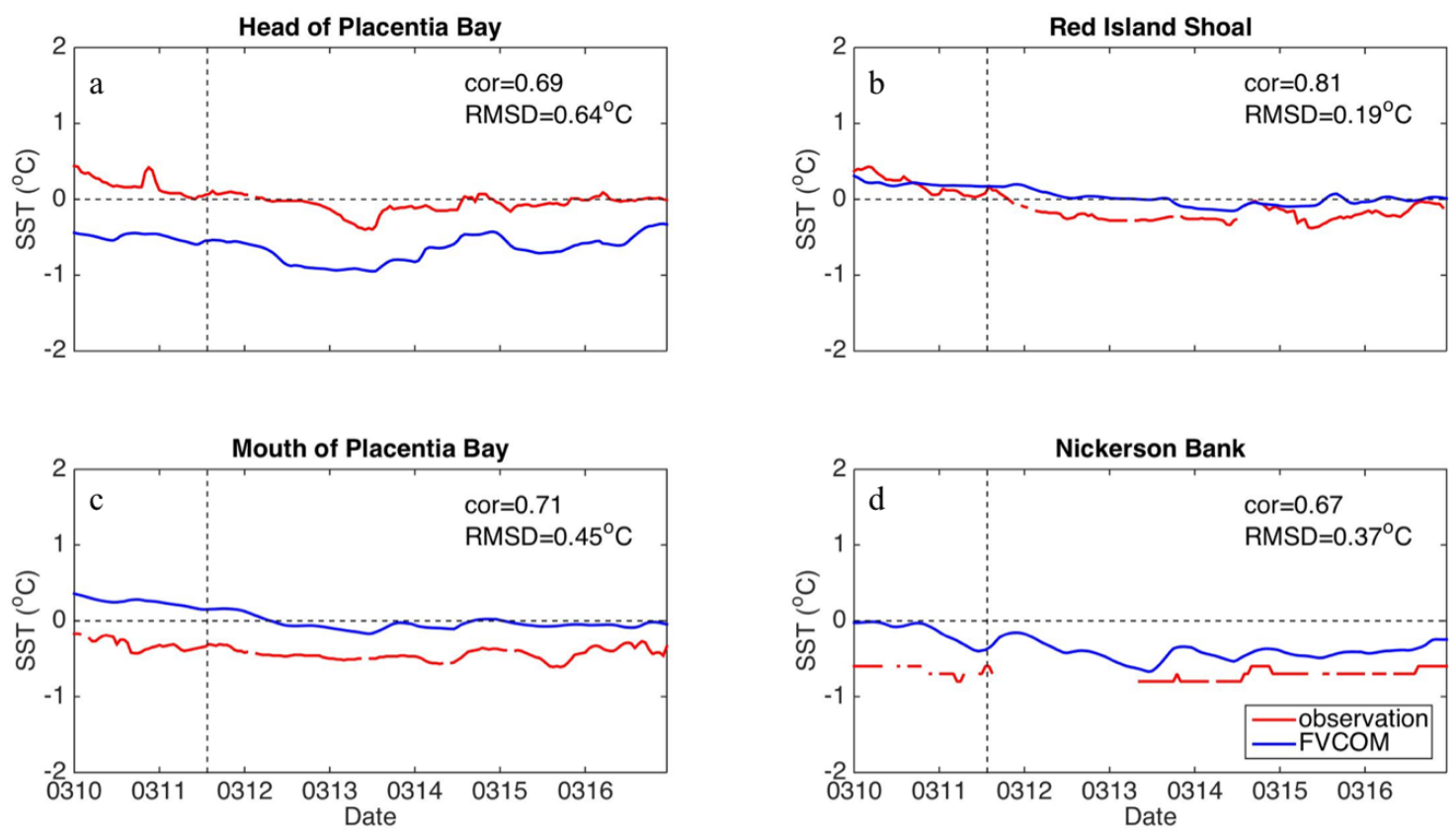

Figure 8. Comparison between buoys (red) and modeled (blue) sea surface SST at HP (a), RI (b), MP (c), and NB (d). The horizontal black dashed lines denote SST $=0{ }^{\circ} \mathrm{C}$. The vertical black dashed lines denote the time of landfall.

Next, we examine satellite observations. A slight drop of SST appears in satellite data in Placentia Bay and surrounding waters after the passage of the extratropical cyclone (Figure $9 a, b)$. The biggest drop in the spatially averaged SST for Placentia Bay is $0.89^{\circ} \mathrm{C}$ from 10 March to 14 March (Figure 9f). The discrepancies in the SST changes between satellite and buoy data may be ascribed to the different measurement depths used: the sea surface for the former and $0.5 \mathrm{~m}$ below it for the latter. The sea surface cooling from satellite observations (Figure $9 a, b$ ) is more prominent in the inner and middle bay than in the outer bay, since the outer bay can be strongly influenced by relatively warm shelf water through advection and lateral mixing. The distribution of SST from the FVCOM solutions (Figure 9c,d) presents a similar pattern overall. Nevertheless, there are some notable spatial differences between observed and model SST changes, for which we are unable to pinpoint exact causes. The maximum SST drop from 10 March to 13 March is $0.54{ }^{\circ} \mathrm{C}$ (Figure 9f).

The SST averaged for the three buoy stations drops by $0.42{ }^{\circ} \mathrm{C}$ from 10 March to $13 \mathrm{March}$, which represents the maximal SST change during the storm (Figure 9f). Figure 9e shows the time series of daily air temperatures observed from buoys at RI and NB and from weather station at SL. The air temperature is about $0^{\circ} \mathrm{C}$ before the storm, and drops about $7^{\circ} \mathrm{C}$ during the storm (from 9 March to 12 March). 

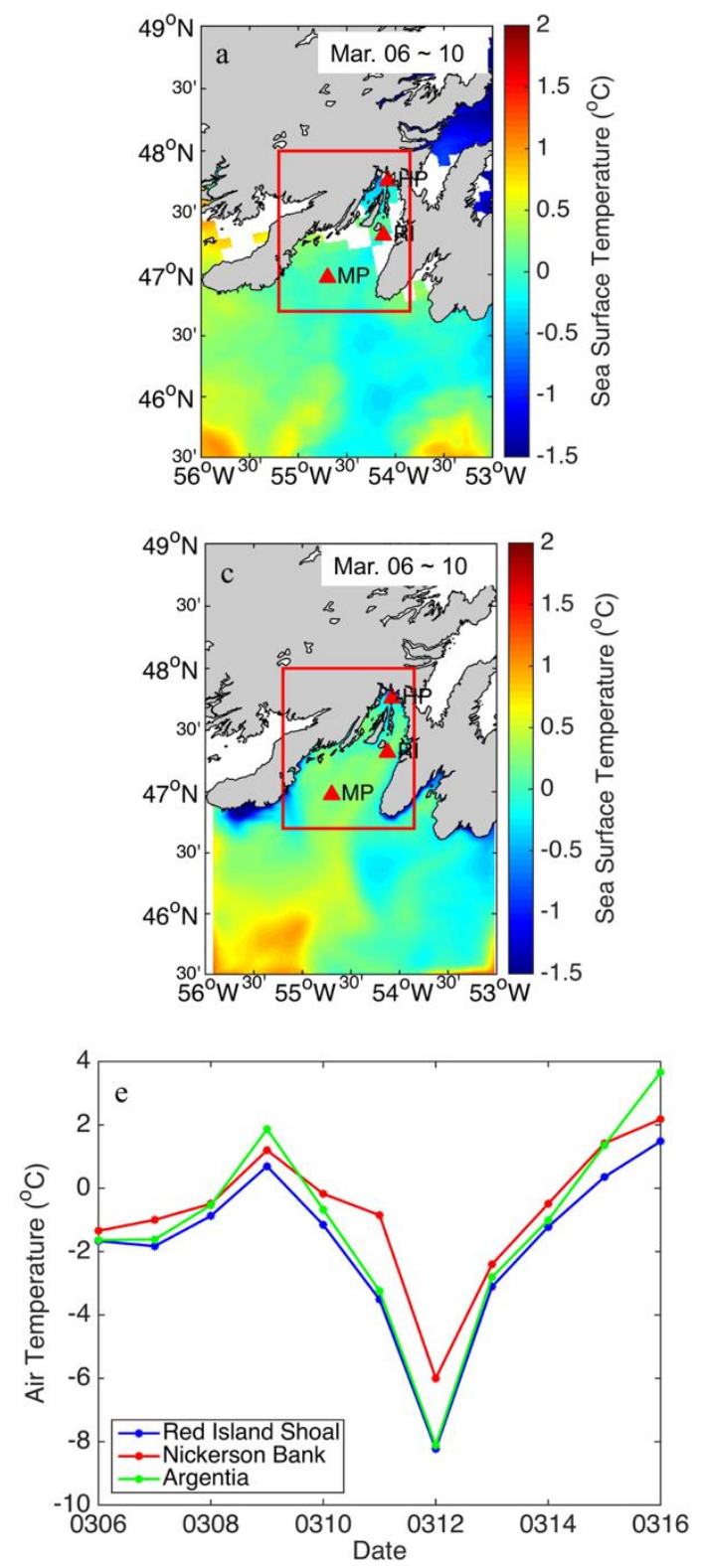
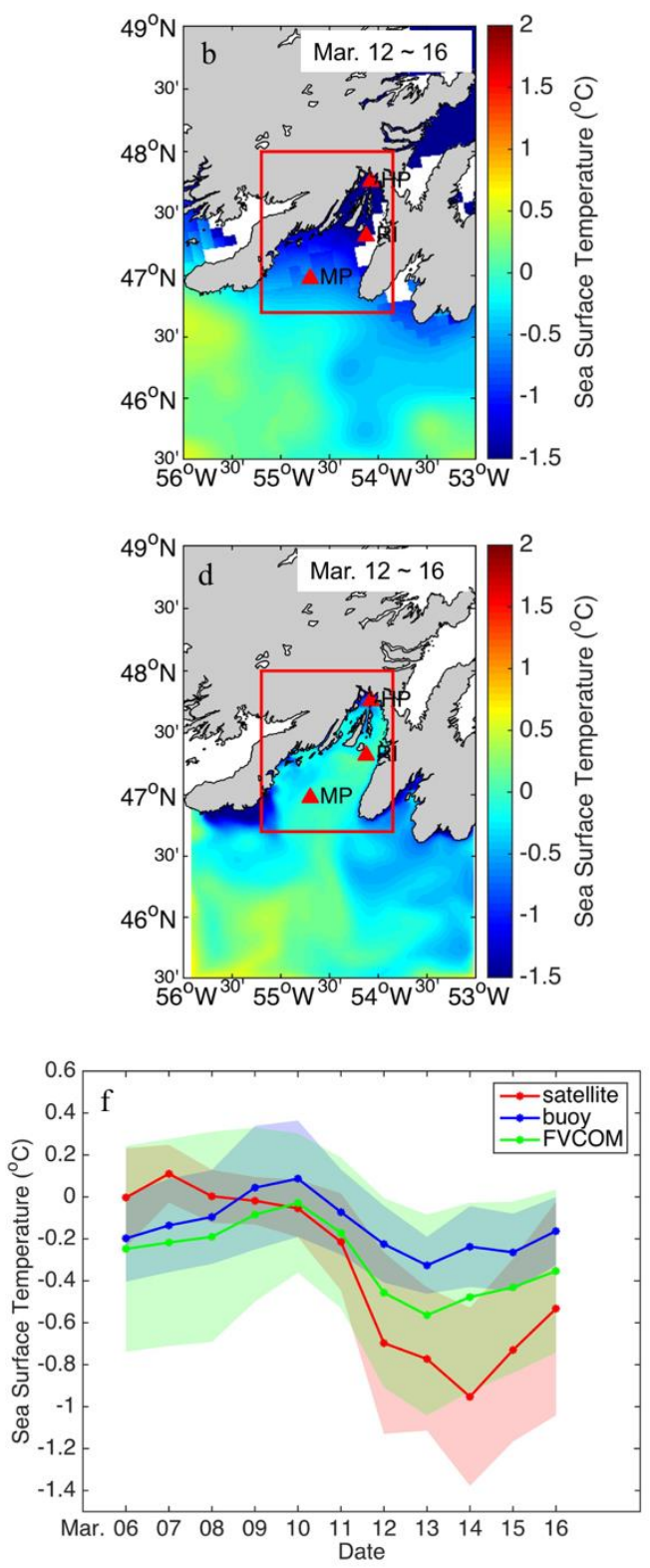

Figure 9. (a,b) Five-day averaged sea surface temperatures observed from satellites before (06-10 March) and after (11-16 March) the passage of the extratropical cyclone. The red squares denote the region in which the spatially averaged sea surface temperatures are calculated. (c,d) same as $(\mathbf{a}, \mathbf{b})$ except for the sea surface temperatures from FVCOM solutions. (e) Time series of daily averaged air temperature from buoys at RI and NB and from the weather station at AG. (f) Time series of daily spatially averaged sea surface temperature from satellite observations (red), buoy measurements (blue) and FVCOM solutions (green) with standard deviations shown as the shadows.

\subsection{Sea Surface Current}

Modeled surface currents are compared with measurements taken at buoys HP, RI, and MP (Figure 10). The buoy measurements show that the storm-induced surface current changes are mainly associated with the zonal component, which is consistent with the dominant wind changes in the zonal direction (Figure 5). As the storm approaching, surface currents at HP (Figure 10a,b) change gradually from eastward to westward and then drastically from westward back to eastward soon after landfall. The surface currents at RI are relatively weak even during the extratropical cyclone (Figure 10c,d) due to its location. At MP, the surface currents turn westward before the extratropical cyclone moves over 
the region (Figure 10e,f). After the storm center passes, the surface currents at MP become eastward under the wind forcing.
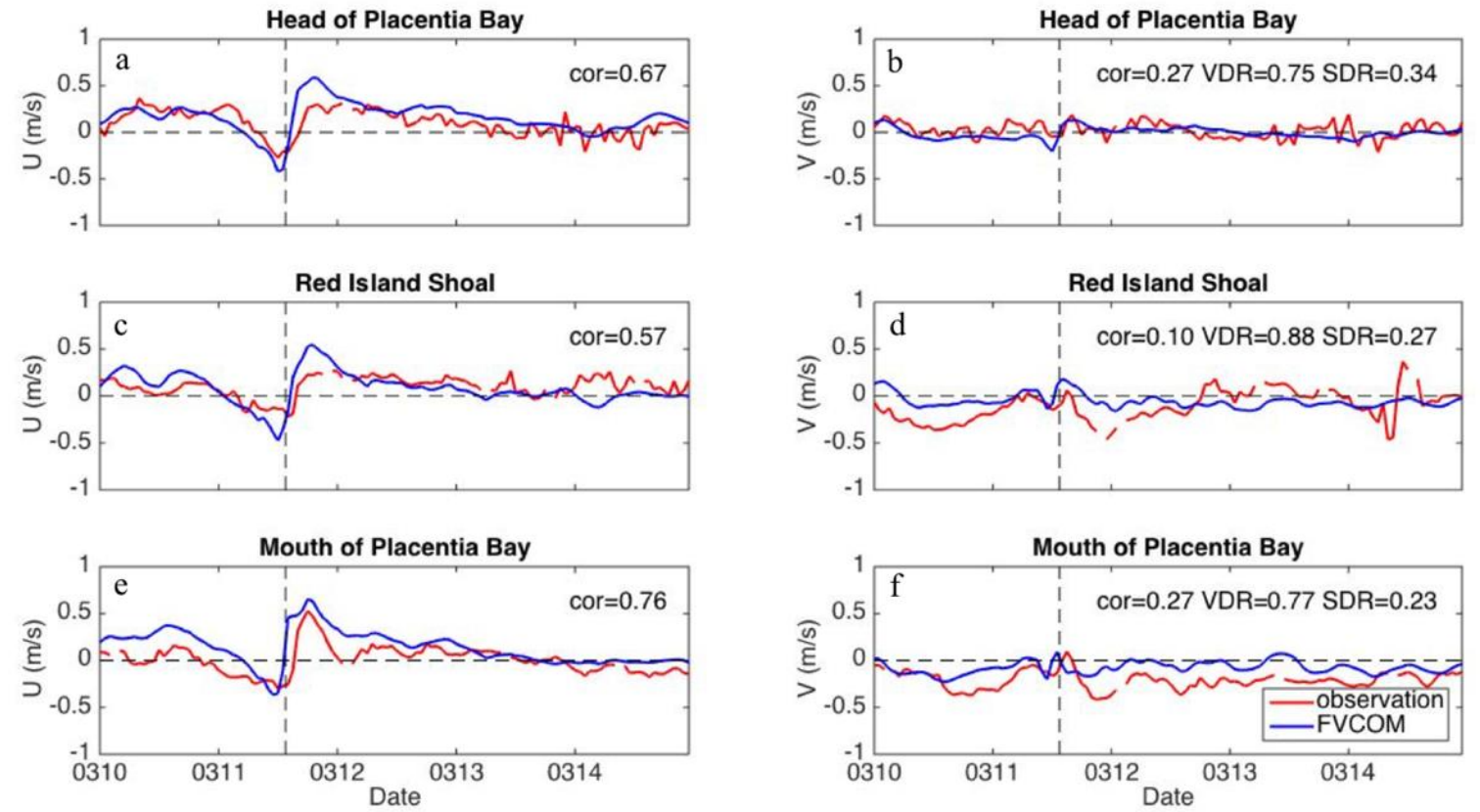

Figure 10. Time series of buoy-measured sea surface currents (red) compared to model results (blue) at $\mathrm{HP}(\mathbf{a}, \mathbf{b}), \mathrm{RI}(\mathbf{c}, \mathbf{d})$ and MP $(\mathbf{e}, \mathbf{f})$. The horizontal black dashed lines denote $\mathrm{U}=0 \mathrm{~m} \mathrm{~s}^{-1}$ and $\mathrm{V}=0 \mathrm{~m} \mathrm{~s}^{-1}$.

The vertical black dashed lines denote the time of landfall.

Statistics calculated between observed and model currents show that the correlation coefficients are greater than 0.5 for the zonal component, which undergoes much larger changes than the meridional component during the storm. The SDR values of the currents during the storm event (from 00:00 on 11 March to 12:00 on 12 March) are small varying from 0.23 to 0.34 at the three buoys, indicating the magnitudes of the model results agree with the observations. On the other hand, the VDR values are larger, varying from 0.75 to 0.88 , indicating fair agreement between model solutions and observed data.

There is no indication of near-inertial oscillation in neither observed nor modeled currents, since the ocean had little stratification in the vertical. Previous studies [7] showed strong inertial oscillation after the passage of hurricanes at MP in summer when the ocean was well stratified in the vertical. Vertical stratification favors the generation of the near-inertial oscillation during a storm [7].

\section{Discussion}

\subsection{Storm Surge Mechanisms}

There are several processes generating storm surge, including winds, atmospheric pressure, tide-surge interaction [38]. Ma et al. [7] investigated the storm surges in Placentia Bay during Hurricanes Igor on 21 September 2010 and Leslie on 11 September 2012. They found the peak storm surge is significantly influenced by local wind-driven and inverse barometric effects during Leslie at Argentia and St. Lawrence, but predominately due to remote forcing during Igor, depending on the storm track location.

To identify the dominant processes for the storm surge during this winter storm, we carried out a series of model experiments with three different forcing configurations, namely, atmospheric forcing only, tide forcing only, and atmospheric and tide forcing combined. The corresponding non-tidal sea levels are denoted as $\eta_{N T}, \eta_{T O}$, and $\eta_{A T}$, respectively. Then the tide-surge interaction $\eta_{T S I}$ for the storm 
follows $\eta_{T S I}=\eta_{A T}-\eta_{T O}-\eta_{N T}$. The inverse barometric response is defined as the sea surface height variation caused by an atmospheric pressure fluctuation $p_{\text {atm }}$ :

$$
\eta=-\frac{p_{a t m}}{\rho_{0} g}
$$

where $\eta$ is the sea surface height variation, $g$ is the gravitational acceleration, and $\rho_{0}$ is the reference water density. The wind effect can then be determined by subtracting $\eta$ from $\eta_{N T}$.

The barometric pressure declines by $54 \mathrm{hPa}$ from 00:00 to 15:00 on 11 March, when the extratropical cyclone moves toward Placentia Bay. The lowest barometric pressure is $954 \mathrm{hPa}$ at AG, inducing a sea surface height increase of $0.58 \mathrm{~m}$ that accounts for $75 \%$ of the observed storm surge $(0.77 \mathrm{~m})$ (Figure 11a). At SL, the sea surface height increase caused by the inverse barometric effect reached $0.46 \mathrm{~m}$, about 56 percent of the observed storm surge (Figure 11b). Therefore, the peak storm surge is mainly associated with the inverse barometric response at AG, and to a lesser degree at SL.
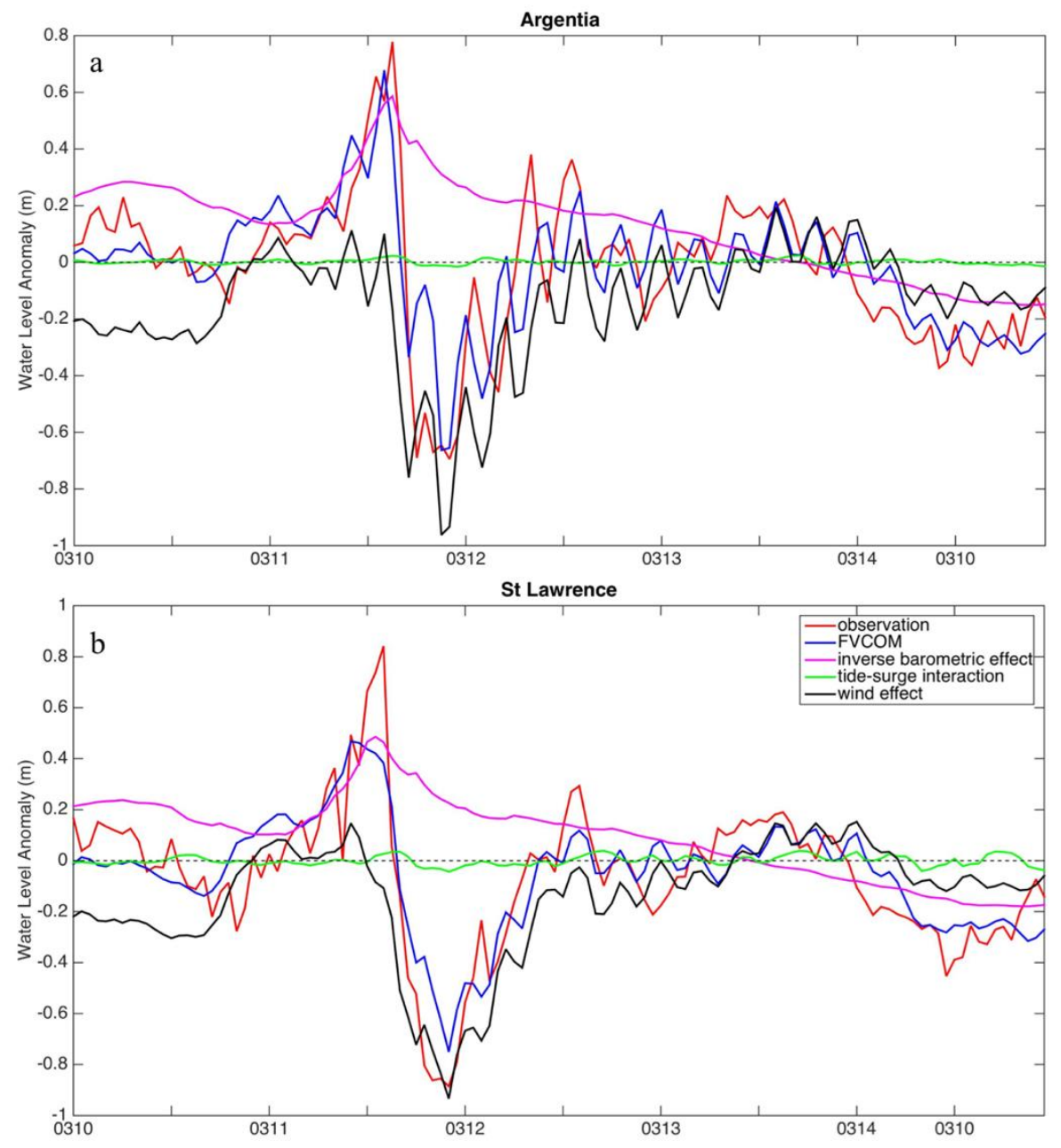

Figure 11. Time series of the non-tidal sea level anomalies (m) from observations (red) and model results (blue), the inverse barometric effect (purple), the tide-surge interaction (green), and the wind effect (black) at AG (a) and SL (b).

It is well known that Ekman transport induced by winds plays an important role in generating coastal storm surge. In this extratropical cyclone event, the wind effect is much weaker than the inverse barometric effect for the peak surge at AG (Figure 11a), due to quite low atmospheric pressure and relatively weak winds before and during landfall. Strong eastward wind with speed more than $15 \mathrm{~m} \mathrm{~s}^{-1}$ (Figure 12a) lasts for several days after landfall. The eastward wind induces Ekman transport 
which pushes water out of the bay, causing the water level in the bay to drop by about $1.3 \mathrm{~m}$ from 14:00 to 21:00 on 11 March. Therefore, the large negative surge is mainly due to the wind effect.
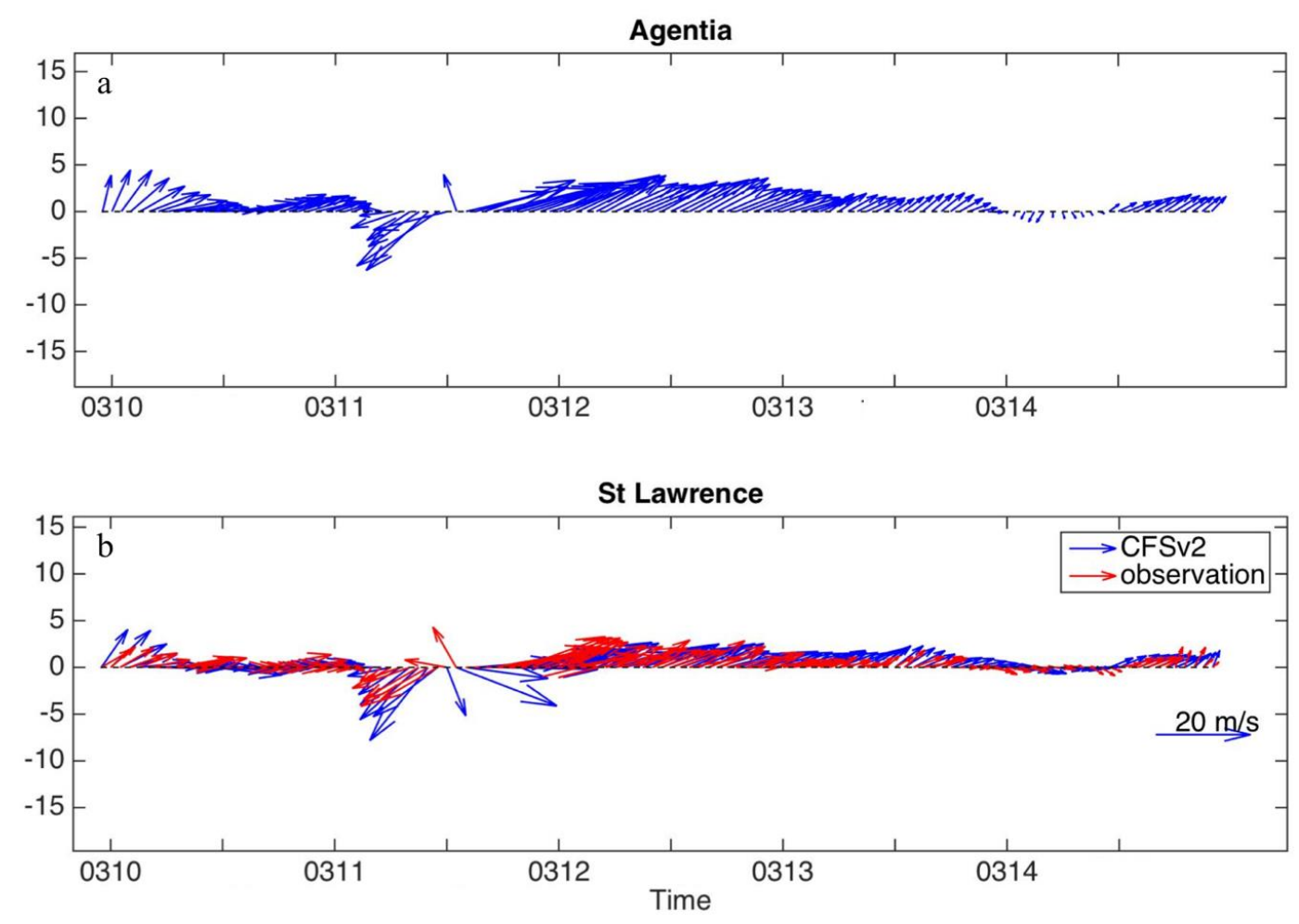

Figure 12. Hourly wind vectors $\left(\mathrm{m} \mathrm{s}^{-1}\right)$ from CFSv2 (blue) and weather station observations (red) at AG (a) and SL (b) from 10 to 14 March 2017.

Mecking et al. [39] used a barotropic shallow-water model to simulate coastal sea level change around the southeastern Newfoundland in response to Tropical Storm Helene (2000) passing over the Grand Banks. It was found that a combination of wind stress and atmospheric pressure forcing caused a meteorological tsunami. The dynamic response to the wind forcing and atmospheric pressure forcing resulted in sea level increase and decrease at Argentia, respectively. Note that the dynamic pressure response here is different from the inverse barometric effect.

At SL, the observed wind speed and directions are quite different from those of CFSv2 from 12:00 to 13:00 on 11 March (Figure 12b). The northwestward winds would induce northeastward Ekman transport, causing the water level to increase. However, the southeastward winds from CFSv2 would induce offshore Ekman transport, causing the water level to decrease in the model results. As a result, the model would underestimate the contribution of winds to the peak storm surge at SL. Following Ma et al. [7], we reconstruct wind fields by blending wind observations at the weather stations and buoys with CFSv2 and use the reconstructed wind fields to force the model. As shown in Figure 13, the model results forced by the reconstructed winds are similar to those forced by the CFSv2 winds, though the reconstructed winds agree well with the observed winds in both magnitude and direction. Therefore, the underestimation of the peak storm surge may be related to something else. While we are not able to pinpoint exact problems, the quality of the open boundary condition may be one of them, since SL is close to the western open boundary. 

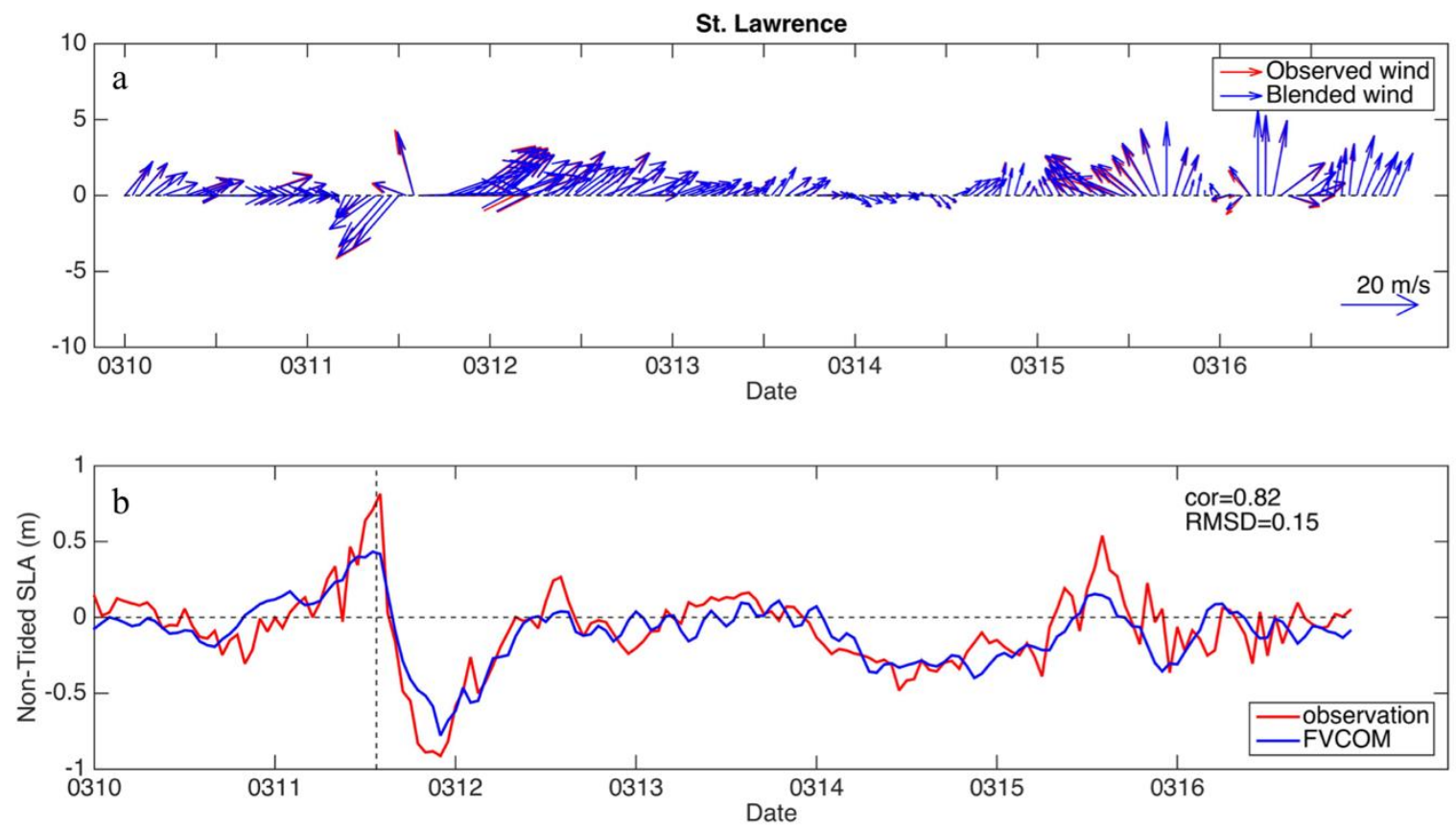

Figure 13. (a) Hourly wind vectors $\left(\mathrm{m} \mathrm{s}^{-1}\right)$ from weather station observations (red) and reconstruction (blue) at SL from 10 to 16 March 2017. (b) Time series of the non-tidal sea level anomalies (m) from observations (red) and model results forced by the reconstructed wind fields (blue) at SL. The horizontal black dashed lines denote non-tide SLA $=0 \mathrm{~m}$. The vertical black dashed lines denote the time of landfall.

\subsection{Momentum Balance}

The momentum balance is analyzed at MP. The momentum equations and the continuity equation used in FVCOM [40] are:

$$
\begin{gathered}
\underbrace{\frac{\partial u}{\partial t}}_{\text {acceleration }}=\underbrace{f v}_{\text {Coriolis }}-\underbrace{\frac{1}{\rho_{0}} \frac{\partial p}{\partial x}}_{\text {pressure gradient }}-\underbrace{\left(u \frac{\partial u}{\partial x}+v \frac{\partial u}{\partial y}+w \frac{\partial u}{\partial z}\right)}_{\text {advection }}+\underbrace{\frac{\partial}{\partial z}\left(K_{m} \frac{\partial u}{\partial z}\right)}_{\text {vertical diffusion }}+\underbrace{\frac{\partial}{\partial x}\left(\mathcal{A} \frac{\partial u}{\partial x}\right)+\frac{\partial}{\partial y}\left(\mathcal{A} \frac{\partial u}{\partial y}\right)}_{\text {horizontal diffusion }}, \\
\underbrace{\frac{\partial v}{\partial t}}_{\text {acceleration }}=\underbrace{-f u}_{\text {Coriolis }}-\underbrace{\frac{1}{\rho_{0}} \frac{\partial p}{\partial y}}_{\text {pressure gradient }}-\underbrace{\left(u \frac{\partial v}{\partial x}+v \frac{\partial v}{\partial y}+w \frac{\partial v}{\partial z}\right)}_{\text {advection }}+\underbrace{\frac{\partial u}{\partial z}\left(K_{m} \frac{\partial v}{\partial z}\right)}_{\text {vertical diffusion }}+\underbrace{\frac{\partial}{\partial x}\left(\mathcal{A} \frac{\partial v}{\partial x}\right)+\frac{\partial v}{\partial y}\left(\mathcal{A} \frac{\partial v}{\partial y}\right)}_{\text {horizontal diffusion }},
\end{gathered}
$$

where $x, y$, and $z$ are the zonal, meridional, and vertical coordinates, respectively; $u, v$ and $w$ are the $x, y$, and $z$ velocity components, respectively; $f$ is the Coriolis parameter; $g$ is the gravitational acceleration; $\rho_{0}$ is the reference water density; $p$ is the pressure; $K_{m}$ is the vertical eddy viscosity; and $\mathcal{A}$ is the horizontal eddy viscosity.

Based on the model results, four dominant terms are considered: Coriolis, pressure gradient, advection, and horizontal diffusion terms. The other terms are smaller by a few orders of magnitude. Figure 14 shows the anomalies of the main terms in the $\mathrm{x}$ - and $\mathrm{y}$-directions at $5 \mathrm{~m}$ below the surface at MP. The anomalies are relative to the means over the period from 8 March to 14 March. Before the extratropical cyclone, the variations of the Coriolis term and pressure gradient term were large and thus played dominant roles in the momentum balance in both directions, while those of the advection 
term and horizontal diffusion term were relatively small. As the storm was approaching, magnitudes of the pressure gradient term and the Coriolis term changed from less than $1 \times 10^{-5} \mathrm{~m} \mathrm{~s}^{-2}$ to more than $2 \times 10^{-5} \mathrm{~m} \mathrm{~s}^{-2}$. The variability of the advection term increased by about $1 \times 10^{-5} \mathrm{~m} \mathrm{~s}^{-2}$ as well. After the storm, the Coriolis term and the pressure gradient term became dominant again.
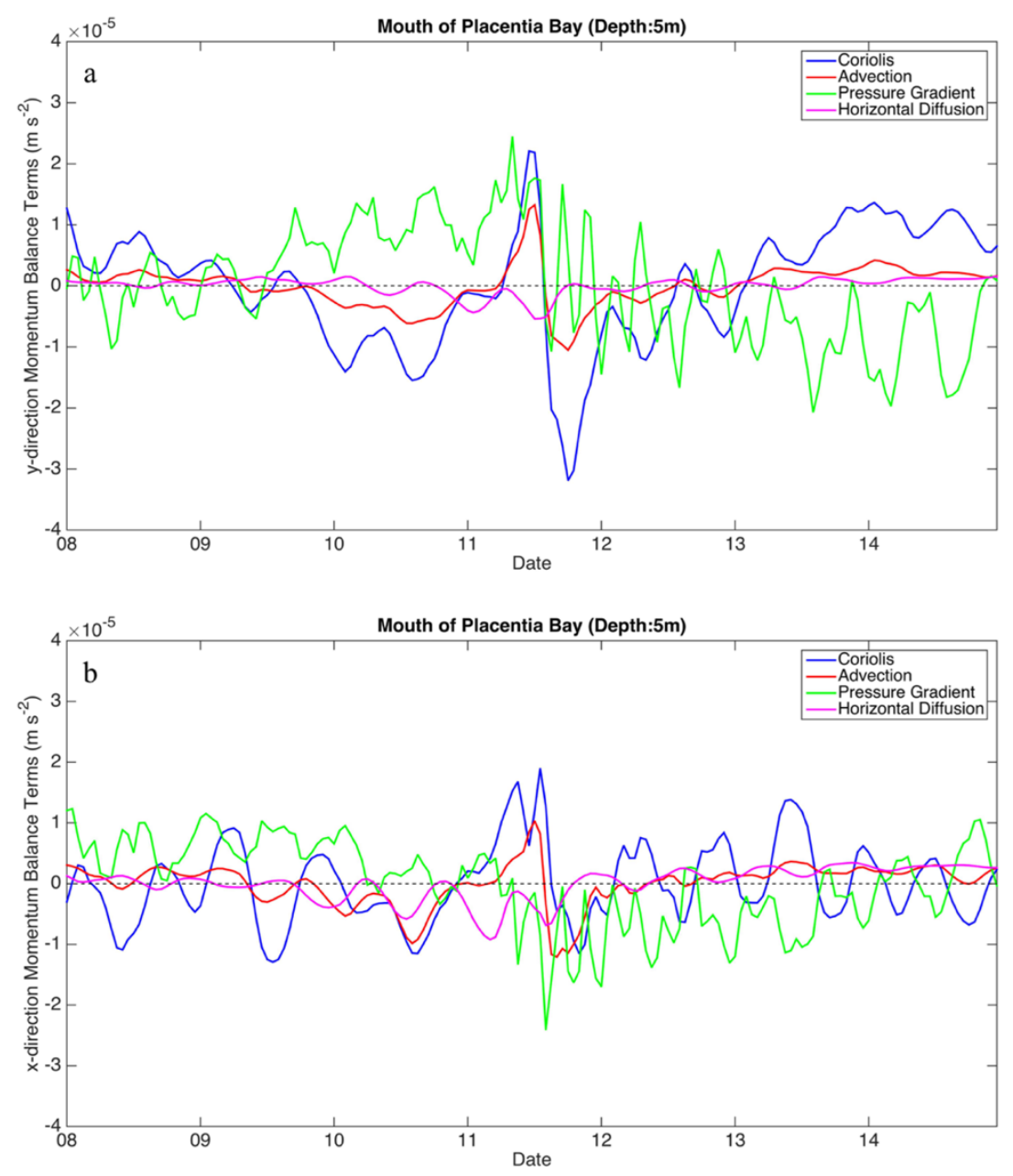

Figure 14. Anomalies of Coriolis term (blue), advection term (red), pressure gradient term (green) and horizontal diffusion term (purple) in the x-direction (a) and the y-direction (b).

The root mean square (RMS) values of the Coriolis and pressure gradient terms are about four times of other terms in the $\mathrm{x}$ and $\mathrm{y}$ directions during the pre- and post-storm periods (Table 1), suggesting that the momentum balance is predominated by the Coriolis and pressure gradient terms. During the storm event (from 12:00 on 10 March to 12:00 on 12 March), the RMS values of all terms increased. The Coriolis and pressure gradient terms were about one to two times greater than the other terms. 
Table 1. Root mean square values of the terms in the momentum balance at MP. (units: $10^{-6} \mathrm{~m} \mathrm{~s}^{-2}$ ).

\begin{tabular}{|c|c|c|c|}
\hline \multirow{2}{*}{ c } & & \multicolumn{2}{|r|}{$5 \mathrm{~m}$} \\
\hline & & During Storm ${ }^{1}$ & Before and After Storm ${ }^{2}$ \\
\hline \multirow{2}{*}{ Coriolis } & $x$ & 8.74 & 5.64 \\
\hline & $\mathrm{y}$ & 14.85 & 7.50 \\
\hline \multirow{2}{*}{ pressure gradient } & $\mathrm{x}$ & 8.17 & 6.84 \\
\hline & $\mathrm{y}$ & 12.21 & 8.31 \\
\hline \multirow{2}{*}{ advection } & $x$ & 6.42 & 2.08 \\
\hline & $\mathrm{y}$ & 6.13 & 2.06 \\
\hline \multirow{2}{*}{ horizontal diffusion } & $\mathrm{x}$ & 4.42 & 1.98 \\
\hline & $\mathrm{y}$ & 2.52 & 0.85 \\
\hline
\end{tabular}

${ }^{1}$ During the storm refers to the period from 12:00 on 10 March to 11:00 on 12 March; ${ }^{2}$ before and after storm refers to the period from 00:00 on 09 March to 11:00 on 10 March and the period from 12:00 on 12 March to 00:00 on 14 March.

\subsection{Differences in Responses to Winter and Summer Storms}

Using satellite observations, Han et al. [6] found that Hurricane Igor in September 2010 made SST decrease by about $6^{\circ} \mathrm{C}$ for the area shallower than $200 \mathrm{~m}$ southeast of Newfoundland. The SST cooling in Placentia Bay during Hurricane Igor was about $3^{\circ} \mathrm{C}$ and that during Hurricane Leslie was about $2{ }^{\circ} \mathrm{C}$ [7]. During these tropical storms, colder subsurface water was brought upward to the near surface layer through vertical mixing, leading to sea surface cooling.

In contrast, the present study reveals a different mechanism of sea surface cooling in response to a winter storm. Figure 15 shows the temporal evolution of temperature at MP during 9-13 March 2017. The temperature is nearly uniform in the vertical before the storm. The storm brings much colder air (Figure 9e) and enhances oceanic heat loss at sea surface. As a result, the ocean temperature in the upper $100 \mathrm{~m}$ decreases by about $0.3{ }^{\circ} \mathrm{C}$. Note that the vertical distribution of modelled oceanic temperature needs to be validated against observations which however are unavailable at the present. Using a regional coupled air-sea model, Nelson and He [14] also found that a winter extratropical cyclone enhanced ocean heat loss over the Gulf Stream.

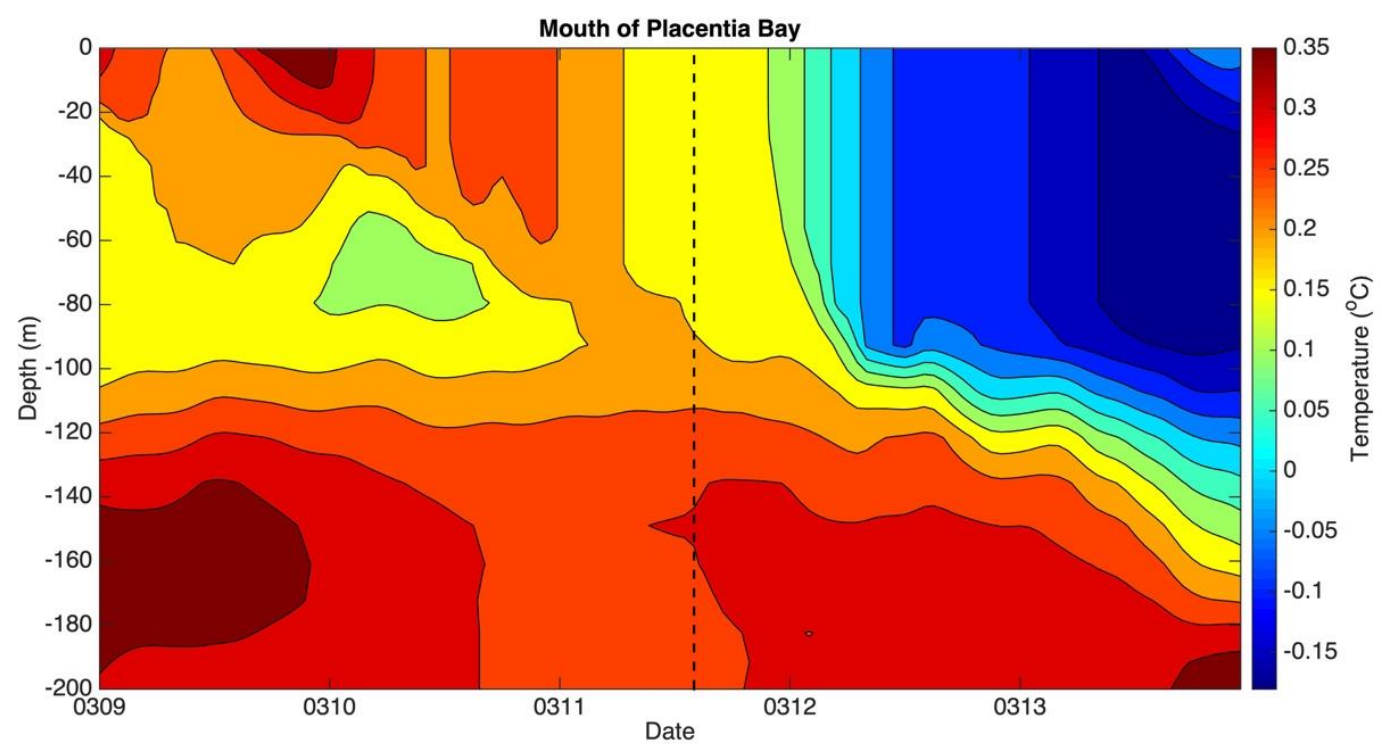

Figure 15. Temporal evolution of temperature during the winter storm. The black dashed line denotes the time when the extratropical cyclone made landfall. The contour interval is $0.05{ }^{\circ} \mathrm{C}$.

In terms of ocean currents, Ma et al. [7] showed strong inertial oscillation after the passage of hurricanes at MP in summer when the ocean was well stratified in the vertical. Vertical stratification 
favors the generation of the near-inertial oscillation during a storm [7]. In contrast, there is no indication of near-inertial oscillation in neither observed nor modeled currents in response to the winter storm (Figure 10), since the ocean had little vertical stratification.

\section{Summary and Conclusions}

Using satellite measurements, in situ data and model results, we investigate the response of Placentia Bay to the extratropical cyclone of 11 March 2017, which is reported to have the largest wind speed in Newfoundland in more than a decade. The peak wind speed observed by the buoys in Placentia Bay reaches $26.6 \mathrm{~m} \mathrm{~s}^{-1}$ during the extratropical cyclone event. The storm surge induced by the extratropical cyclone is detected by tide-gauge stations and the Jason-3 altimeter. The maximum storm surges at St. Lawrence (SL) and Argentia (AG) were $0.85 \mathrm{~m}$ and $0.77 \mathrm{~m}$, respectively, during the storm. Both buoy and satellite observations show a slight SST drop, $0.42{ }^{\circ} \mathrm{C}$ from the former and $0.65{ }^{\circ} \mathrm{C}$ from the latter.

The Finite-Volume Community Ocean Model (FVCOM) is employed to examine the oceanic response to the storm in Placentia Bay. The magnitude of storm surge from the model generally agrees with observations, with RMSDs of about $0.15 \mathrm{~m}$. However, the model is noted to underestimate the peak surges at SL. The model captures the slight SST drop during the storm. The root-mean-square differences (RMSDs) of SST between the model and buoy observations are less than $0.7^{\circ} \mathrm{C}$. The model surface current changes agree fairly with observations, with SDRs of $0.23-0.34$ and VDRs of $0.75-0.88^{\circ} \mathrm{C}$.

The model storm surge results indicate that the inverse barometric response plays an important role in generating the peak surge at AG and SL due to quite low air pressure and relatively weak winds before and during landfall. The subsequent negative surge is mainly due to the wind effect associated with relatively strong eastward winds at both stations.

The model ocean temperature change reveals that the sea surface cooling is associated with the oceanic heat loss during the storm that brings much colder air. There is no indication of near-inertial oscillation in response to the winter storm, due to little oceanic stratification in the vertical.

The variations of major terms in the governing equation at the $5 \mathrm{~m}$ depth at MP indicate that the storm perturbs the pre-storm momentum balance which is dominated by the Coriolis term and the pressure gradient term. As a result, the advection term and horizontal diffusion term become important as well during the storm. The Coriolis term and the pressure gradient term become dominant again after the storm passes.

In future work, we plan to improve the open boundary conditions by using a regional ocean model output, which may help improve the storm surge simulation. Including precipitation and evaporation in the atmospheric forcing can be another aspect for enhancement. Furthermore, the FVCOM model can be coupled with an atmospheric model and a surface wave model to better simulate atmosphere-ocean-wave interactions during winter storms. In addition, more observations, such as vertical profiles data, should be collected and applied to validate the model results.

Author Contributions: Conceptualization, G.X. and G.H.; methodology: G.X.; validation: G.X. and G.H.; formal analysis: G.X.; writing: G.X., G.H., and C.D.; supervision: G.H., C.D., J.Y., and B.D.

Funding: This research was funded by National Key Research and Development Program of China (2017YFA0604100, 2016YFA0601803), the National Natural Science Foundation of China $(41476022,41490643)$, the Startup Foundation for Introducing Talent of Nanjing University of Information Science and Technology (2014r072), the Program for Innovation Research and Entrepreneurship team in Jiangsu Province (2191061503801), the National Programme on Global Change and Air-Sea Interaction (GASI-03-IPOVAI-05), the National Science Foundation of China (OCE 06-23011), the foundation of China Ocean Mineral Resources R and D Association (DY135-E2-2-02, DY135-E2-3-01), and Jiangsu Province, PR China for providing financial support through the Programme for Postgraduate Cultivation and Innovation (KYLX16_0925). This work is also supported by China Scholarship Council and by the Surface Water and Ocean Topography-Canada (SWOT), and the Canadian Space Agency.

Acknowledgments: The authors thank NASA/JPL (https://podaac.jpl.nasa.gov/dataset/), AVISO (https://www. ghrsst.org/), Canadian Hydrographic Service (http://www.charts.gc.ca/), SmartAtlantic (http://www.smartatlantic. ca/PlacentiaBay/), AZMP (https://www.canada.ca/en/services/environment/weather.html), and the National Ocean 
Partnership Program (https://rda.ucar.edu/) for providing the data used in this study. GX thanks Zhimin Ma and Yingda Xie for helping set up the FVCOM model and Nancy Chen for help processing and analyze satellite altimetry data.

Conflicts of Interest: The authors declare no conflict of interest.

\section{References}

1. Bernier, N.B.; Thompson, K.R. Predicting the frequency of storm surges and extreme sea levels in the Northwest Atlantic. J. Geophys. Res. Ocean. 2006, 111, C10009. [CrossRef]

2. Chen, C.; Beardsley, R.C.; Luettich, A.L., Jr.; Westerink, J.J.; Wang, H.; Perrie, W.; Xu, Q.; Donahue, A.S.; Qi, J.; Lin, H.; et al. Extratropical storm inundation tested: Inter-model comparisons in Scituate, Massachusetts. J. Geophys. Res. Ocean. 2013, 118, 5054-5073. [CrossRef]

3. Bradbury, I.R.; Snelgrove, P.V.; Fraser, S. Transport and development of eggs and larvae of Atlantic cod, Gadus morhua, in relation to spawning time and location in coastal Newfoundland. Can. J. Fish. Aquat. Sci. 2000, 57, 1761-1772. [CrossRef]

4. Han, G.; Ma, Z.; Chen, D.; DeYoung, B.; Chen, N. Observing storm surges from space: Hurricane Igor off Newfoundland. Sci. Rep. 2012, 2, 1010. [CrossRef] [PubMed]

5. Ma, Z.; Han, G.; DeYoung, B. Oceanic responses to Hurricane Igor over the Grand Banks: A modeling study. J. Geophys. Res. Ocean. 2015, 120, 1276-1295. [CrossRef]

6. Han, G.; Ma, Z.; Chen, N. Hurricane Igor impacts on the stratification and phytoplankton bloom over the Grand Banks. J. Mar. Syst. 2012, 100, 19-25. [CrossRef]

7. Ma, Z.; Han, G.; DeYoung, B. Modelling the response of Placentia Bay to hurricanes Igor and Leslie. Ocean Model. 2017, 112, 112-124. [CrossRef]

8. Catto, J.L. Extratropical cyclone classification and its use in climate studies. Rev. Geophys. 2016, 54, 486-520. [CrossRef]

9. Orton, P.M.; Hall, T.M.; Talke, S.A.; Blumberg, A.F.; Georgas, N.; Vinogradov, S. A validated tropical-extratropical flood hazard assessment for New York Harbor. J. Geophys. Res. Ocean. 2016, 121, 8904-8929. [CrossRef]

10. Hirsch, M.E.; DeGaetano, A.T.; Colucci, S.J. An East Coast Winter Storm Climatology. J. Clim. 2001, 14, 882-899. [CrossRef]

11. Colle, B.A.; Booth, J.F.; Chang, E.K.M. A review of historical and future changes of extratropical cyclones and associated impacts along the US East Coast. Curr. Clim. Chang. Rep. 2015, 1, 125-143. [CrossRef]

12. DeGaetano, A.T. Predictability of seasonal east coast winter storm surge impacts with application to New York's Long Island. Meteorol. Appl. 2008, 15, 231-242. [CrossRef]

13. Booth, J.F.; Rieder, H.E.; Lee, D.E.; Kushnir, Y. The paths of extratropical cyclones associated with wintertime high-wind events in the northeastern United States. J. Appl. Meteorol. Clim. 2015, 54, 1871-1885. [CrossRef]

14. Nelson, J.; He, R. Effect of the Gulf Stream on winter extratropical cyclone outbreaks. Atmos. Sci. Lett. 2012, 13, 311-316. [CrossRef]

15. Hurricane-force Winds Wreak Havoc in Newfoundland. Available online: https://www.theglobeandmail. com/news/national/brier-play-stopped-as-extreme-winds-batter-newfoundland/article34275289/ (accessed on 17 April 2017).

16. Valladeau, G.; Thibaut, P.; Picard, B.; Poisson, J.C.; Tran, N.; Picot, N.; Guillot, A. Using SARAL/AltiKa to improve Ka-band altimeter measurements for coastal zones, hydrology and ice: The PEACHI prototype. Mar. Geod. 2015, 38 (Suppl. 1), 124-142. [CrossRef]

17. Ray, R.D. Precise comparisons of bottom-pressure and altimetric ocean tides. J. Geophys. Res. Ocean. 2013, 118, 4570-4584. [CrossRef]

18. Cartwright, D.E.; Edden, A.C. Corrected tables of tidal harmonics. Geophys. J. R. Astron. Soc. 1973, 33, 253-264. [CrossRef]

19. Wahr, J.M. Deformation induced by polar motion. J. Geophys. Res. Solid Earth 1985, 90, 9363-9368. [CrossRef]

20. Martin, M.; Dash, P.; Ignatov, A.; Banzon, V.; Beggs, H.; Brasnett, B.; Cayula, J.F.; Cummings, J.; Donlon, C.; Gentemann, C.; et al. Group for High Resolution Sea Surface Temperature (GHRSST) analysis fields inter-comparisons. Part 1: A GHRSST multi-product ensemble (GMPE). Deep Sea Res. Part II 2012, 77-80, 21-30. [CrossRef] 
21. Dash, P.; Ignatov, A.; Martin, M.; Donlon, C.; Brasnett, B.; Reynolds, R.W.; Banzon, V.; Beggs, H.; Cayula, J.F.; Chao, Y.; et al. Group for High Resolution Sea Surface Temperature (GHRSST) analysis fields inter-comparisons-Part 2: Near real time web-based level 4 SST Quality Monitor (L4-SQUAM). Deep Sea Res. Part II 2012, 77-80, 31-43. [CrossRef]

22. Saha, S.; Moorthi, S.; Wu, X.; Wang, J.; Nadiga, S.; Tripp, P.; Behringer, D.; Hou, Y.T. The NCEP climate forecast system version 2. J. Clim. 2014, 27, 2185-2208. [CrossRef]

23. Bleck, R.; Halliwell, G.R., Jr.; Wallcraft, A.J.; Carroll, S.; Kelly, K.; Rushing, K. Hybrid Coordinate Ocean Model (HYCOM) User's Manual: Details of the Numerical Code. Available online: http://hycom.rsmas.miami.edu (accessed on 12 May 2017).

24. Chen, C.; Liu, H.; Beardsley, R.C. An unstructured grid, finite-volume, three-dimensional, primitive equations ocean model: Application to coastal ocean and estuaries. J. Atmos. Ocean. Technol. 2003, 20, 159-186. [CrossRef]

25. Rego, J.L.; Li, C. Storm surge propagation in Galveston Bay during Hurricane Ike. J. Mar. Syst. 2010, 82, 265-279. [CrossRef]

26. Han, G.; Ma, Z.; DeYoung, B.; Foreman, M.; Chen, N. Simulation of three-dimensional circulation and hydrography over the Grand Banks of Newfoundland. Ocean Model. 2011, 40, 199-210. [CrossRef]

27. Burchard, H.; Bolding, K.; Villarreal, M.R. GOTM, a General Ocean Turbulence Model: Theory, Implementation and Test Cases; Technical Reports; Space Applications Institute: Gujarat, India, 1999.

28. Mellor, G.L.; Ezer, T.; Oey, L.Y. The pressure gradient conundrum of sigma coordinates ocean models. J. Atmos. Ocean. Technol. 1994, 11, 1126-1134. [CrossRef]

29. Ma, Z.; Han, G.; DeYoung, B. Modelling temperature, currents and stratification in Placentia Bay. Atmos. Ocean 2012, 50, 244-260. [CrossRef]

30. Egbert, G.D.; Erofeeva, S.Y. Efficient inverse modeling of barotropic ocean tides. J. Atmos. Ocean. Technol. 2002, 19, 183-204. [CrossRef]

31. Dong, C.; McWilliams, J.C.; Hall, A.; Hughes, M. Numerical simulation of a synoptic event in the Southern California Bight. J. Geophys. Res. Ocean. 2011, 116, C05018. [CrossRef]

32. Jiang, J.; Perrie, W. The impacts of climate change on autumn north Atlantic midlatitude cyclones. J. Clim. 2007, 20, 1174-1187. [CrossRef]

33. Yao, Y.; Perrie, W.; Zhang, W.; Jiang, J. Characteristics of atmosphere-ocean interactions along North Atlantic extratropical storms tracks. J. Geophys. Res. Atmos. 2008, 113, D14124. [CrossRef]

34. Han, G.; Lu, Z.; Wang, Z.; Helbig, J.; Chen, N.; DeYoung, B. Seasonal variability of the Labrador Current and shelf circulation off Newfoundland. J. Geophys. Res. Ocean. 2008, 113, C10013. [CrossRef]

35. Pawlowicz, R.; Beardsley, B.; Lentz, S. Classical tidal harmonic analysis including error estimates in MATLAB using T_TIDE. Comput. Geosci. 2002, 28, 929-937. [CrossRef]

36. Han, G.; Ma, Z.; Chen, N.; Chen, N.; Yang, J.; Chen, D. Hurricane Isaac storm surges off Florida observed by Jason-1 and Jason-2 satellite altimeters. Remote Sens. Environ. 2017, 198, 244-253. [CrossRef]

37. Sheng, J.; Zhai, X.; Greatbatch, R.J. Numerical study of the storm-induced circulation on the Scotian Shelf during Hurricane Juan using a nested-grid ocean model. Prog. Oceanogr. 2006, 70, 233-254. [CrossRef]

38. Bunya, S.; Dietrich, J.C.; Westerink, J.J.; Ebersole, B.B.; Smith, J.M.; Atkinson, J.H.; Jensen, R.; Resio, D.T.; Luettich, R.A.; Dawson, C.; et al. A high-resolution coupled riverine flow, tide, wind, wind wave, and storm surge model for Southern Louisiana and Mississippi. Part I: Model Development and Validation. Mon. Weather Rev. 2010, 138, 345-377. [CrossRef]

39. Mecking, J.V.; Fogarty, C.T.; Greatbatch, R.J.; Sheng, J.; Mercer, D. Using atmospheric model output to simulate the meteorological tsunami response to Tropical Storm Helene (2000). J. Geophys. Res. Ocean. 2009, 114, C10005. [CrossRef]

40. Chen, C.; Huang, H.; Beardsley, R.C.; Liu, H.; Xu, Q.; Cowles, G. A finite volume numerical approach for coastal ocean circulation studies: Comparisons with finite difference models. J. Geophys. Res. Ocean. 2007, 112, C03018. [CrossRef]

(C) 2019 by the authors. Licensee MDPI, Basel, Switzerland. This article is an open access article distributed under the terms and conditions of the Creative Commons Attribution (CC BY) license (http://creativecommons.org/licenses/by/4.0/). 